\title{
Eco-hydrology and the effects on the national economy: case of the eastern region of Abakaliki Anticlinorium, Southeastern Nigeria
}

\author{
Stephen Nwoba Ukpai ${ }^{1} \cdot$ Hilary Nwogboduwhu Ezeh ${ }^{1} \cdot$ Solomon Chukwuedum Effam ${ }^{1}$
}

Received: 27 May 2019 / Accepted: 16 January 2020 / Published online: 31 January 2020

(c) The Author(s) 2020

\begin{abstract}
The area was mineralized, yet it is an agricultural settlement. Histories of water hardness and local migration of connate (saline) water exist across the region. This study investigated effects of these geogenic circumstances on the economy of the region and Nigeria. Geophysical and geochemical analyses were carried out for delineation of hydrological structures relevant to groundwater movement and pollution status, respectively. Results revealed silty-sandy shale sandwiched between 60 and $100 \Omega$-m at the fourth geoelectric layer. This layer marks depths to water table from 7.0 to $12.0 \mathrm{~m}$ and formed aquitard as medium of regional stance for groundwater percolation. The aquitards confined localized resistivity anomalies of $\leq 60 \Omega-\mathrm{m}$ and was interpreted as various aquifers. Isolated peaks of hydraulic head up to $85 \mathrm{~m}$ around north-western and south-eastern ends of NW-SE-trending local water divide indicated areas of water table crops where conjunctive hydrological interaction exists between surface water and groundwater resources; each flushes dissolved elements from the calcareous sediments into the water resources. Consequently, configurations of $\mathrm{pH}$, total dissolved solutes (TDS), electrical conductivity (EC) and total hardness ranged as: 6.97-7.96, 20-1399 mg/l, 30-2100 $\mu \mathrm{s} / \mathrm{cm}$ and 8-160 mg/l, respectively. Localized concentrations of calcium, sodium, bicarbonate, sulphate, chloride, iron, manganese, zinc, lead, chromium and cobalt in $\mathrm{mg} / \mathrm{l}$ ranged to pollution or alert levels as follows: $38-590,5-89,10-126,30-460,6-128,0.01-1.74,0.1-0.41,0.001-0.13,0 / 01-1.98$, $0.011-0.56$ and $0.05-0.22$, respectively. The water is therefore hard and hence supports encrustations of fittings for water supplies. Consequently, screens' slot sizes were clogged, resulting in incessant boreholes failures in the region. Heavy metals are polluting from identifiable loading sources, possibly, due to the proximity of associated lodes. These pollution(s) caused the exceedance of TDS (as reflected in EC) above the saline borderline and hence the salinity and sodium hazards that hampered crop growth, mainly cereal foods. It also endangered biodiversity of adjoining downstream regions.
\end{abstract}

Keywords Water supply $\cdot$ Economy $\cdot$ Calcareous shale $\cdot$ Chemical facies $\cdot$ Solutes $\cdot$ Watershed

\section{Introduction}

Chemical parameters of water resources could be influenced by hydrological interaction with geological formations (Subramani et al. 2005) and affect the utilization potential, especially in agriculture (Food and agriculture organization, FAO 2013). Based on this condition, water supply and sanitation services were initiated (African Ministers' Council on Water (AMCOW 2011)) as management strategy (National Water Policy, NWP 2004) to ensure excellence of water supply in agriculture for food production, in industries for

Stephen Nwoba Ukpai

ukpaisteve@gmail.com

1 Department of Geology and Exploration Geophysics, Ebonyi State University, Abakaliki, Nigeria processing and production efficiency, and in households for smooth services. This would meet the poverty eradication objective of sustainable development goals (SDGs), particularly in developing nations, comprising Nigeria. Thus, it was within the scope of this study to present a dataset vis-à-vis information relevant in the water supply and sanitation services to the concerned stakeholders, organizations and agencies of water sector, using the case of Abakaliki Province. Specifically, the focus was to develop data from this case as a reference for global viewpoint on watershed planning and development. The case study covers a watershed around eastern flank of Abakaliki Anticlinorium that sandwiches both regional and local river catchments at the Southeastern Nigerian edge of Benue Trough (Fig. 1). It comprises a municipal around the downstream with population greater than 277,000 people (National Bureau of Statistics, NBS 


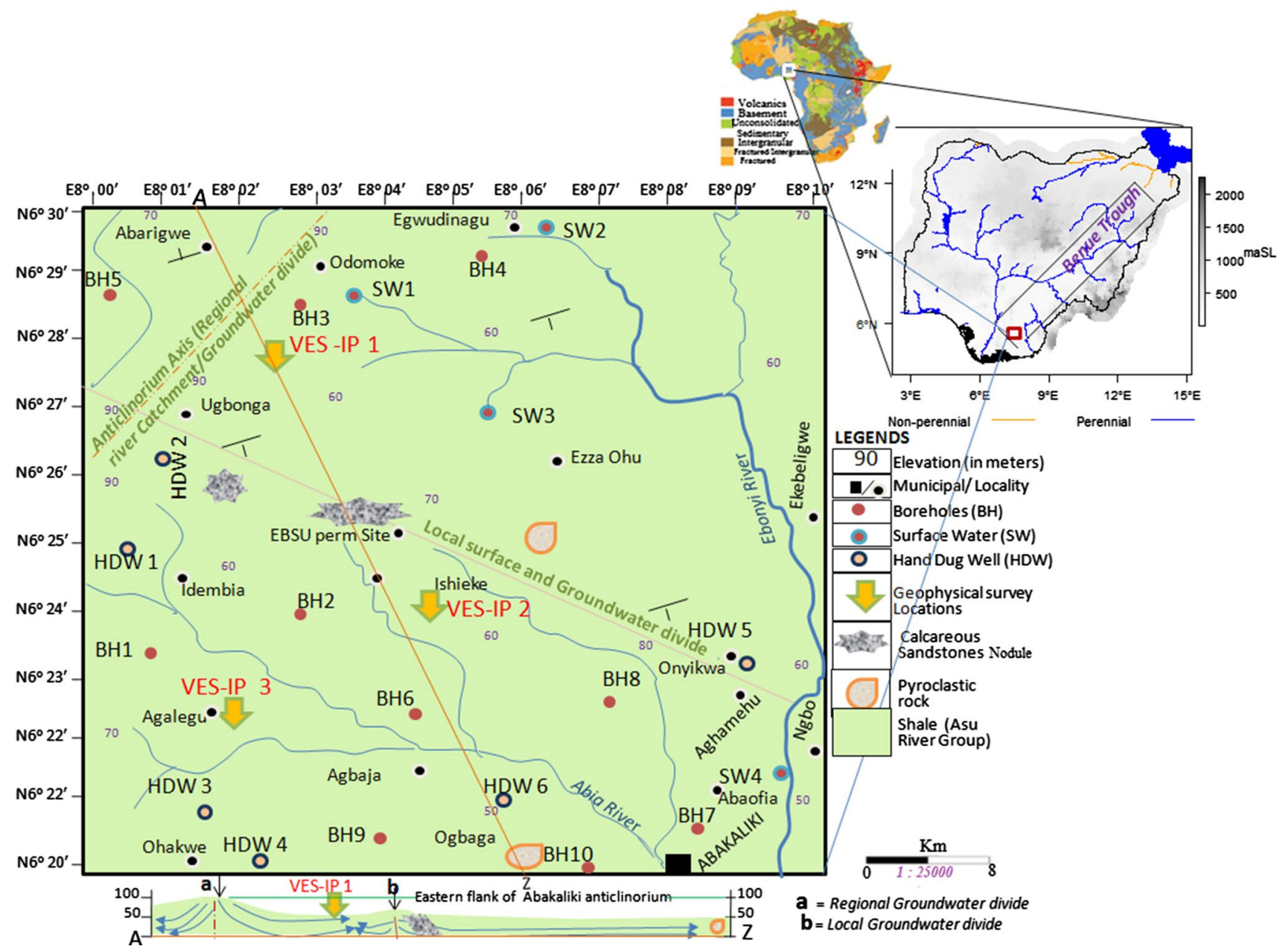

Fig. 1 Hydrogeological map of the studied watershed

2011). The region is underlain mainly by ammonite-rich blue-black shales (Ojoh 1992) that package ore minerals in some places (Umeji 2000; Obiora and Umeji 2004; Oha et al. 2016). Weathering affected the bedrocks in many parts via natural and anthropogenic processes and hence formed soil that generally supported food crop production. However, dissolved solutes released from the weathered potions, in addition to those permeating from run-off sediments, mine water plumes and connate source, concentrated beyond nutritional limits in the water resources. Winter et al. (1998) had noted that movement of water between groundwater and surface water provides major pathways for chemical transfer between terrestrial and aquatic systems. The transfer of chemicals (dissolved solutes or ions) exposes biodiversity to bioavailability of the ions; hence, the purpose of this study was to evaluate the extent of ionic concentrations, mode of chemical movement and the ecological risk assessment with respect to the national economy.

Tijani et al. (2018) reported mineralization of water resources in the entire lower Benue Trough, mainly due salt and ore deposits, even as Okogbue and Ukpai (2013) and Obiora et al. (2016) had earlier related such mineralization at Abakaliki axis of the trough to point source loading from active and derelict mine sites. But then, due to the dispersed calcareous sediments at the eastern flank of Abakaliki Anticlinorium, the present study traced the pollution units to both continuous non-points (or dispersed) loading sources and the point sources. The study therefore alerted vulnerability of the populace of the region at downstream areas to bioaccumulation of toxin from the water supplies. Apart from identifying the cause of brown colouration of food cooked with water from boreholes, which had remained unknown, this research attributed problematic groundwater development from endemic borehole failures in the area to the groundwater chemistry. Although water hardness controls the chemistry, positive impact was noted as the hard nature limits ion mobility in pipe-borne water supply. The overall negative impacts on the biotic community have integral effects on the economy of Nigeria. 


\section{Physiographical, geological and hydrological setting}

The studied watershed lies between latitude $6^{\circ} 20^{\prime} \mathrm{N}$ and $6^{\circ} 30^{\prime} \mathrm{N}$, and from longitude $8^{\circ} 00^{\prime} \mathrm{E}$ to $8^{\circ} 10^{\prime} \mathrm{E}$. The area is located within tropical savannah region of Southeastern Nigeria, characterized by almost equal period of dry and rainy seasons. Annual mean precipitation (rainfall) is as high as $2000 \mathrm{~mm}$ (Areola et al. 1992) with monthly mean temperature greater than $18{ }^{\circ} \mathrm{C}$ (McKnight and Hess 2000). It supports tall grasses, shrubs cover and scanty, but evergreen tall trees. However, leaves of ephemeral plants (or food crops) are locally yellowish and pale green in some parts of the region. Apart from calcareous sandstones (Fig. 12 in Appendix) locally exposed at various parts of Abakaliki watershed, the area is mainly underlain by low-permeable aquiclude formed by shale bedrock. The shales turn silty at weathered parts, most of which was possibly identified by Adelana et al. (2008) as subordinate siltstones units, all belong to Asu River Group of Albian age. The sediments are fossiliferous (Agumanu 1989) due to the abundance of ammonites like Mortoniceras and Elobiceras spp. (Reyment 1965). Petters (1983) identified calcareous fossils of microspecies like Heterohelix and Hedbergella forams, in addition to palynoflora of dinoflagellate cysts reported in Umeji (2013). Pyroclastics were isolatedly emplaced in almost N-S trend and are mainly quarried for engineering constructions. Heaps of dust from the quarry works and other mine tailings were washed by overland flow as run-off sediments and were drained to Ebonyi River (Fig. 13 in Appendix), whereas some permeate to the groundwater systems with effluent from mine pits and solution cavities.

\section{Methodology}

Three traverse locations, namely VES-IP 1, VES-IP 2 and VES-IP 3 (see Fig. 1), were selected for VES-IP survey in order to mirror the subsurface geology from north to south. Measurements were taken across traverse lines in north-south orientations, each stretched to a maximum of about $300 \mathrm{~m}$ (i.e. $\mathrm{AB} / 2=150 \mathrm{~m}$ ). The $\mathrm{AB}$ is distance between two current electrodes designated as $\mathrm{C} 1$ and $\mathrm{C} 2$, which were inserted to the ground to inject electrical current into the subsurface. A transmitter (Geomatics-20) received potential differences $(\Delta V)$ by two potential electrodes (P1 and P2) separated to the distance, MN between the current electrodes via Schlumberger array (see raw data in Table 5a-c in Appendix). Tomographic model of the traverse line was produced from resistivity aspects (Res 1, Res 2 and Res 3) of the VES-IP survey using IP12 software.
Depths to water levels (DWL) were measured from handdug wells (HDWs) using dip meter (Heron model), and the hydraulic heads were analysed as the differences between topographic elevations and the DWL (Ukpai et al. 2016) as shown in Table 6 in Appendix. Twenty water samples were collected at various locations (see Fig. 1) for hydrogeochemical analysis: 6 from HDW, 10 from boreholes (BH) and 4 from surface water (SW). Each sample was filtered into 1-1 bottle rinsed with filtered alliquote using 0.45 micro-membrane filter paper. The samples were transported (in cooled condition after being refrigerated to temperature between 20 and $25^{\circ} \mathrm{C}$ ) to UNICEF-developed laboratory, Ibadan, Nigeria, for chemical analysis.

Statistical softwares were used to subject the laboratory results to interpretative platforms, like graphs and tables. Irrigation parameters were analysed thus:

Sodium adsorption ratio (SAR) as (Hussain et al. 2010; Seilsepour and Rashidi 2008):

$\mathrm{SAR}=\frac{\mathrm{Na}^{+}}{\sqrt{\frac{\mathrm{Ca}^{2+}+\mathrm{Mg}^{2+}}{2}}}$

Percentage sodium (Na\%) as (Kacmaz and Nakoman 2010):

$\mathrm{Na} \%=\frac{\left(\mathrm{Na}^{+}+\mathrm{K}^{+}\right) \times 100}{\mathrm{Ca}^{2}+\mathrm{Mg}^{2}+\mathrm{Na}^{+}+\mathrm{K}^{+}}$

Soluble sodium percentage (SSP) as (Satish et al. 2016):

$\mathrm{SSP}=\frac{\mathrm{Na}^{+} \times 100}{\mathrm{Ca}^{2}+\mathrm{Mg}^{2}+\mathrm{Na}^{+}}$

\section{Results and discussion}

\section{Hydrological relevance of geologic structures}

Interpretation of resistivity results with comparative borehole data (Table 1) showed that the shaley bedrock locally changed to baked facie (see Fig. 2). This facie appeared metamorphosed at depth from 5 to $12 \mathrm{~m}$ around $\mathrm{BH} 3$ (Fig. 2a). The baking of the shales can be related to regional metamorphism which affected Abakaliki Province (Obiora and Umeji 2004). The metamorphosed facie weathered to permeable unit at the boundary with saturated zone, perhaps due to the influence of water table flux (Fig. 2a, b). Generally the water table was inferred within the fourth geoelectric unit (see Figs. 3a, 4a, 5a) at depths corresponding to minimum value of apparent resistivity curves: $12 \mathrm{~m}$ around VES 1 (Fig. 3a), about $10 \mathrm{~m}$ at VES 2 (Fig. 4a) and $7.0 \mathrm{~m}$ at VES 3 (Fig. 5a). The fourth geoelectric layer was revealed in $\mathrm{BH} 3$ and $\mathrm{BH} 6$ as silty-sandy shale layer (see Fig. 2a, b). Tomographic model (Fig. 2c) discriminated 


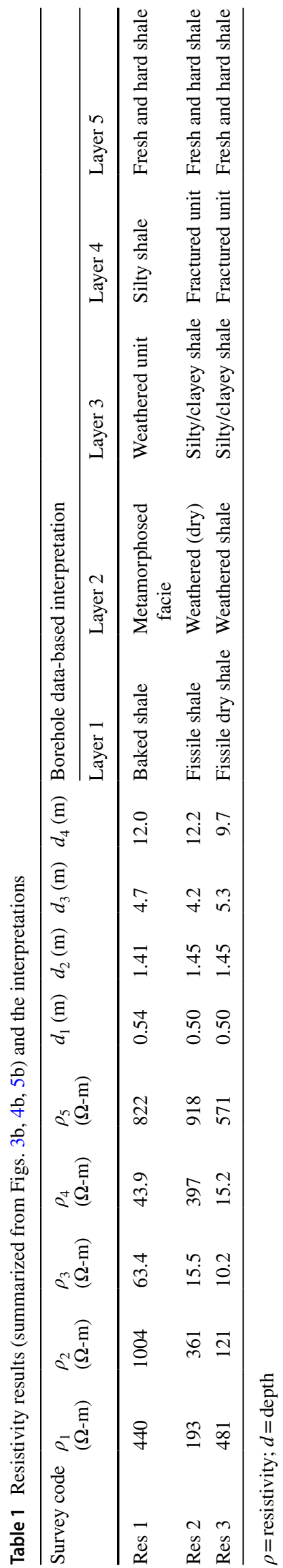

this layer with resistivities ranging from 60 to $100 \Omega$-m, and it appeared to confine aquiferous unit which reflected resistivities of about $60 \Omega-\mathrm{m}$. Further discriminations with integrated VES-IP parameters indicated the argillaceous unit (silty-sandy shale) with an anomaly formed at the points where lower limit of apparent resistivity curve relatively coincided with the upper limit of the apparent chargeability curve (Figs. 3b, 4b).

Typically, clay minerals reflect low resistivity (Odudury and Mamah 2014) and high chargeability (Parkhomenko 2013; Rehman et al. 2016). Seeing from VES-IP 3, the apparent resistivity and chargeability concurrently decayed to the lowest values of about $7.0 \Omega-\mathrm{m}$ and $1.0 \mathrm{~ms}$, respectively (Fig. $5 \mathrm{~b}$ ), forming an anomalous curve from depth of $3 \mathrm{~m}$ to about $35 \mathrm{~m}$ around adjacent BH 6 . The anomaly has been interpreted as isolated aquiferous zone, possibly formed by weathered unit that reflects the maximum resistivity of $60 \Omega-m$ in Fig. 2c. Its alignment towards the surface around Agalegu area at the downstream part of the watershed suggests that the water table is cropping out to fluvial system. Similar hydrological interplay has been suspected along the groundwater divide (Fig. 6) around Ugbonga and Onyikwa areas where the hydraulic heads isolatedly peaked to about $85 \mathrm{~m}$. The hydraulic head at Ugbonga was influenced by topographic elevation which is as high as $90 \mathrm{~m}$ (see Fig. 1). At such topographic elevation, curvature of the water table is typically towards the surface to outcrop at the anticlinal edges and discharge the groundwater to fluvial system. This agrees with Condon and Maxwell (2015) who reported that topography can control configurations of water tables. The water table rises locally above the streambed near Onyikwa axis of Ebonyi River, perhaps in response to the high amount of mean annual rainfalls that had characterized the region. This suggests that the river is effluent, particularly in the rainy season. According to Varni et al. (2013), rises in groundwater level are relatable to precipitation (rainfall). Analogically, soon after periods of precipitation, the raised water table creates pressure head gradient that induce base flow from areas of higher hydraulic elevations (or energy heads). The elevated energy heads aligned along the axis of groundwater divide (Fig. 6) and relatively coincided with axis of outcropped silty/weathered shale at upstream region of the watershed. The silty-sandy shale (aquitards) being saturated within the water table (see Fig. 2a, b) absorbs and stores great deal of water (Montgomery 2011), as well as transmit it from one aquifer to another (Fetter 2007). The aquitards sustain regional groundwater flow (Freeze and Cherry 1979; Todds 1980; Kelvin 2005).

\section{Hydrology of dissolved solutes}

\section{Environmental concentrations and impacts}

Typical calcareous soil is characterized with high rate of infiltration, loss of nutrients through leaching and high $\mathrm{pH}$ 


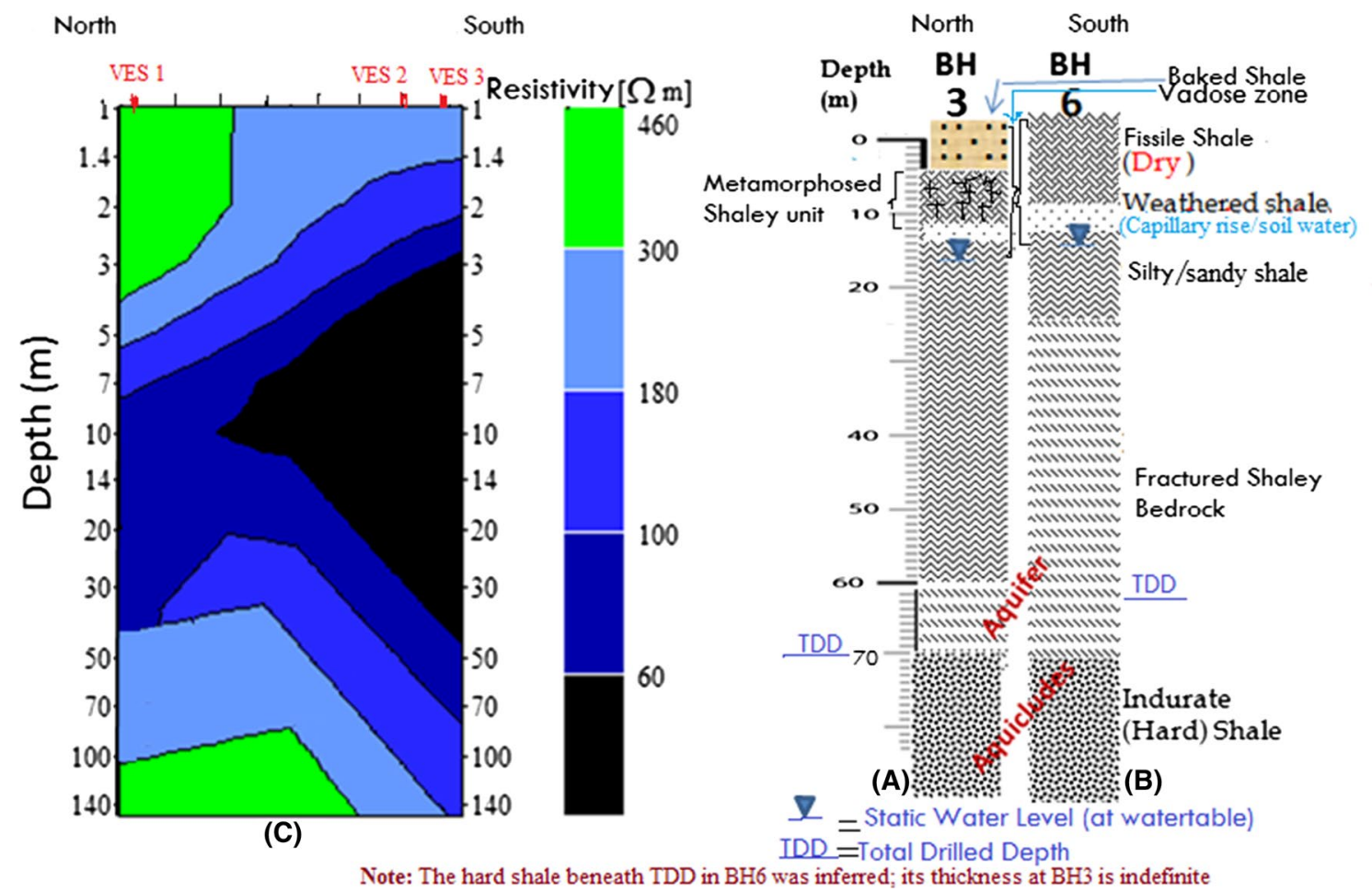

Fig. 2 Integration of drillers' $\operatorname{logs}(\mathbf{a}, \mathbf{b})$ with 1-D tomographically correlated resistivity data from VES 1, VES 2 and VES 3 (c)

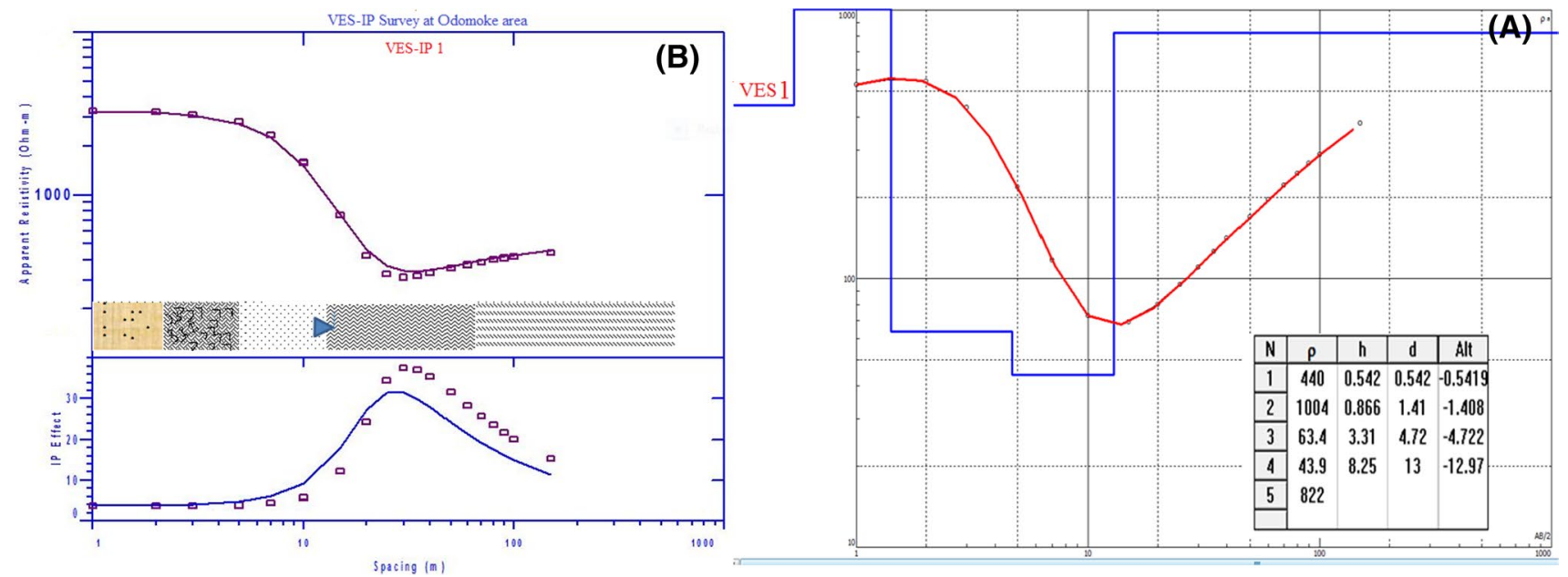

Fig. 3 a Geoelectric units for VES 1 (Odomoke area) with apparent resistivity curve (inset table shows layer resistivities and depths); b VES-IP curves juxtaposed with adjacent borehole ( $\mathrm{BH} 3$ ) data from Odomoke area

level (Aboukila et al. 2016). So, the assimilation of dissolved solutes from the soil modified the $\mathrm{pH}$ to neutral range from 6.97 to 7.96 units (Table 2). Seemingly, the $\mathrm{pH}$ setting activated ample mobility of dissolved solutes (ions) and hence the concentrations of total dissolved solutes (TDS) greater than the permissible limit stipulated by WHO (2011) in many areas (Table 2). The areas comprise locations represented in sample 2 (Ishieke), sample 4 (Ugbonga), sample
5 (Odomoke 1) and sample 7 (Egwudinagu 1). Other locations where the physical parameters polluted include: Abofia 1 (sample 15), Ogbaga 1 (samples 18) and Obegu-Aba (sample 19). Such pollution levels exposed the availability of ions in the manner that deteriorates the ecosystem and by implication affects the biota. For instance, the concentration of TDS which reflected high configuration of electrical conductivity (EC) in sample 2 (BH 2) tends towards freshwater 

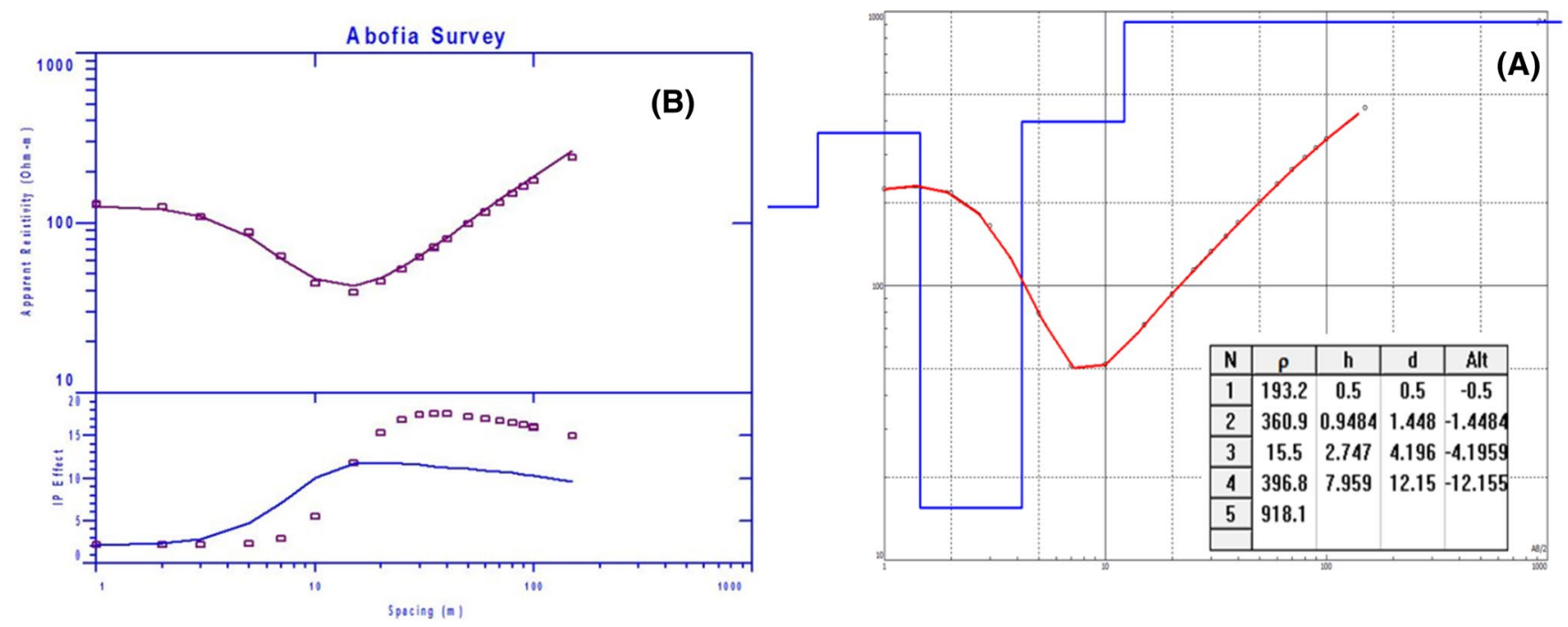

Fig. 4 a Geoelectric units for VES 2 (Abofia area) with the apparent resistivity curve, b VES-IP curves distinguishing geoelectric layers representative lithologies

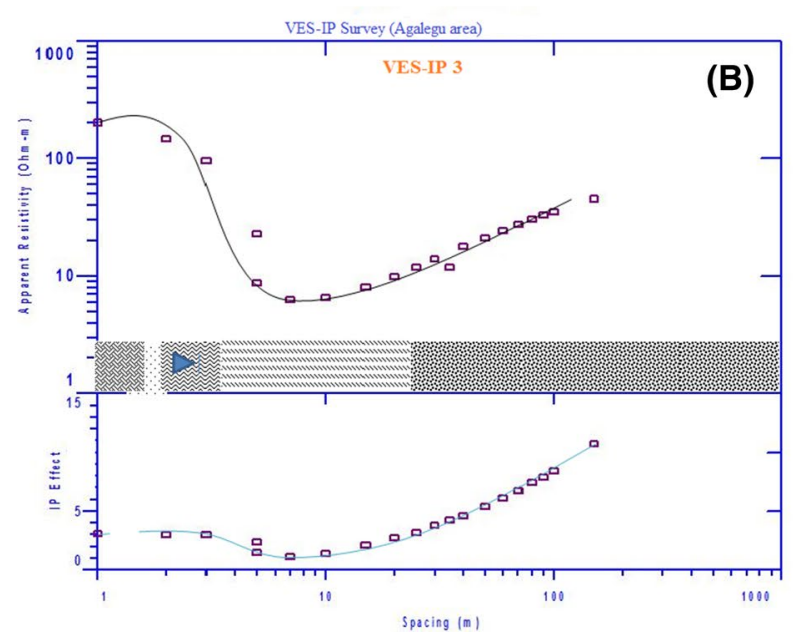

Fig. 5 a Geoelectric units for VES 3 (Agalegu area) with apparent resistivity curve for depth to the water table, b VES-IP curves juxtaposed with adjacent BH 6 data from the Agalegu area. Note: Slight

borderline (i.e. $1000 \mathrm{mg} / \mathrm{l})$ and increases into saltwater range ( $\geq 1000 \mathrm{mg} / \mathrm{l}$ ) in sample 4 (HDW 2), samples 15 (SW 4) and 19 (BH 10) at downstream. Dispersion of TDS on same trend with the surface and groundwater movements (compare Figs. 6, 7 and Figs. 15, 16, 17, 18, 19, 20, 21, 22, 23, 24, 25 in Appendix) suggests solute transport through movement of water and was described as advection by Domenico and Schwartz (1998). It means that solutes disseminating from run-off and stream sediments, as well as dispersed mine water plumes, were advected through tributaries to Ebonyi River that drains the watershed towards downstream region. Likewise, the groundwater system forms major agent

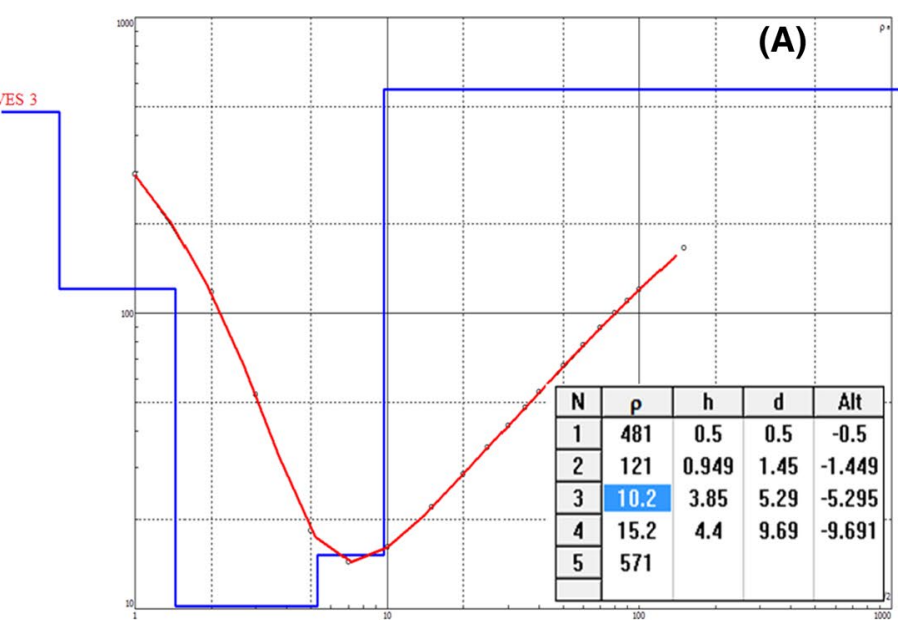

misfit exists between measured depth to water table from the borehole $\log$ and the depth marked from apparent resistivity curve

of advection after the plume had leached into the ground. The advection process therefore exposed vast regions adjoining the watershed to contamination of dissolved solutes.

Dominant trends for cation and anion concentrations as: $\mathrm{Ca}^{2+}>\mathrm{Na}^{+}>\mathrm{Mg}^{2+}>\mathrm{K}$ and $\mathrm{HCO}_{3}{ }^{2-}>\mathrm{Cl}^{-}>\mathrm{SO}_{4}{ }^{2-}$, respectively (Table 2$)$, showed that ions like calcium $\left(\mathrm{Ca}^{2+}\right)$, sodium $\left(\mathrm{Na}^{+}\right)$and magnesium $\left(\mathrm{Mg}^{2+}\right)$, bicarbonate $\left(\mathrm{HCO}_{3}{ }^{-}\right)$, chloride $\left(\mathrm{Cl}^{-}\right)$and sulphate $\left(\mathrm{SO}_{4}{ }^{2-}\right)$ constitute major portion of the TDS. Generally, high concentration of $\mathrm{HCO}_{3}{ }^{-}$in particular infused prevalence of slight acidic-alkaline range of $\mathrm{pH}$ in most of the areas characterized by elevated values of TDS (see Table 2). Contents of other major ions are at 


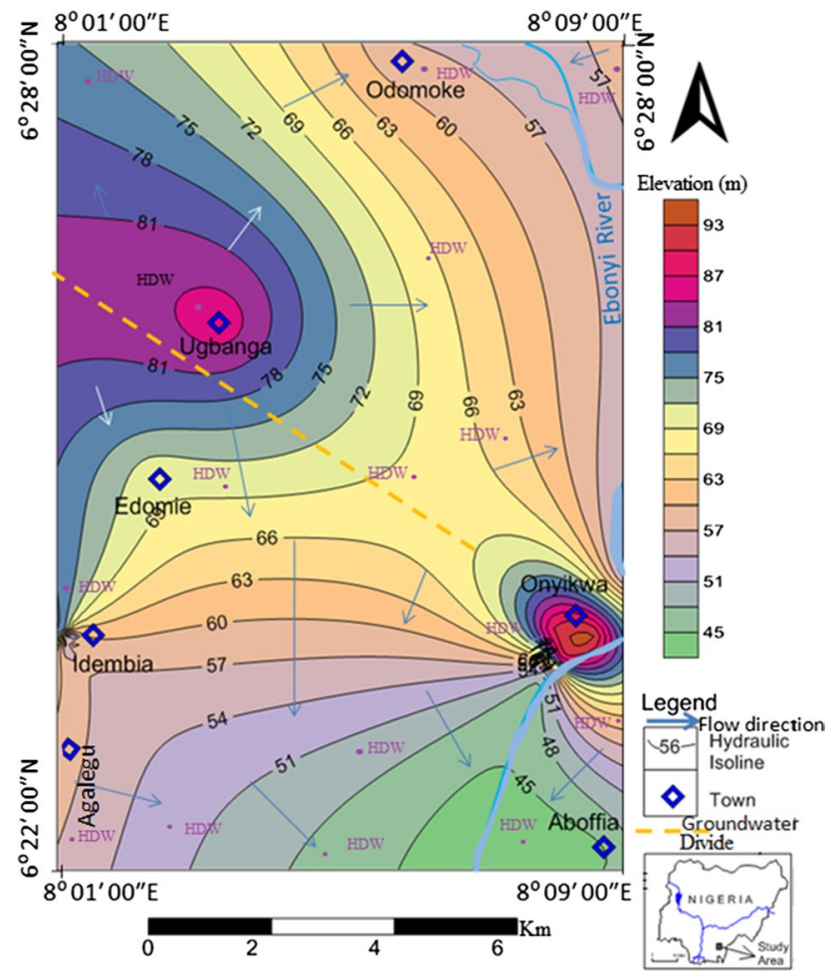

Fig. 6 Map showing hydraulic heads, groundwater flow directions/ divide (raw data in "Appendix")

nutritional importance (or within standard limits) except $\mathrm{SO}_{4}{ }^{2-}$ at Obegu-Aba (sample 19). Also, concentrations of minor ions like potassium $\left(\mathrm{K}^{+}\right)$and nitrate $\left(\mathrm{NO}_{3}{ }^{+}\right)$are generally low, particularly $\mathrm{NO}_{3}{ }^{+}$being much below the permissible limit (see Table 2). The extreme low $\mathrm{NO}_{3}{ }^{+}$may be related to its reduction by denitrifying micro-organisms (Tischner 2000) which reduce nitrates to dinitrogen $\left(\mathrm{N}_{2}\right)$ as shown in Eq. 4, through enzymatic utilization of oxygen component, especially in the neutral $\mathrm{pH}$ condition by which the causative organisms thrive well (Li and Shen 1993). This is due to the high oxygen demand of the water resources due to the inherent anoxic condition of fossiliferous sedimentary environment of the entire watershed and the adjoining regions.

$2 \mathrm{NO}_{3}^{-}+10 \mathrm{e}^{-}+12 \mathrm{H}^{+} \rightarrow \mathrm{N}_{2} \uparrow+6 \mathrm{H}_{2} \mathrm{O}$

In an anoxic (or oxygen depleted) hydrological system like the watershed, biochemical mechanism (Eq. 4) devastated the concentration of nitrate in the soil and possibly minimized the nutritional value of nitrogen, often required in nitrate form by plants (Xu et al. 2012). Thus, soil water at areas underlain by the fossiliferous sediments across the entire lower Benue Trough is therefore vulnerable to the denitrifying effect, resulting in the lack of nitrate-based nitrogen in food crops. For this reason, it is safe to attribute the pale green and yellowish leaves that blotch some food crops, especially maize (Zea mays), rice (Oryza sativa) and some vegetable crops at many parts of the region to this effect.

Other constituents of the TDS are some heavy metals, referred as micro-nutrients (Alloway 2013). Typical calcareous soil suffers from the lack of micro-nutrients (FAO 2019), particularly $\mathrm{Mn}, \mathrm{Zn}, \mathrm{Cu}, \mathrm{Fe}$ (Marschner 1995) as observed in many parts of the watershed. However, localized concentrations of these elements at level greater than permissible limits (see Table 2) indicate continuous loading from the point sources around the watershed. Manganese (Mn), zinc $(\mathrm{Zn})$ and cobalt $(\mathrm{Co})$ are polluting in borehole $(\mathrm{BH} 1)$ around Idembia area, iron $(\mathrm{Fe})$, lead $(\mathrm{Pb})$, chromium $(\mathrm{Cr}), \mathrm{Zn}$ and Co are polluting in $\mathrm{BH} 3$ (Odomoke area); while Fe pollutes the borehole (BH 4) at Egwudinagu area $1, \mathrm{Zn}$ polluted the surface water supply (SW 2 and SW 4) at Abofia area 2 and Egwudinagu area 2. $\mathrm{Fe}, \mathrm{Zn}, \mathrm{Cr}$ and $\mathrm{Co}$ are polluting in $\mathrm{BH}$ 10 (Obegu-Aba area). The elevated concentrations of these micro-nutrients exposed livestock and food crops to bioaccumulation of heavy metals (Blowes et al. 2003), even as inhabitants who ingest water supplied from these sources are vulnerable to bioaccumulation of the toxins.

\section{Correlation with geochemical processes}

In Table 3, correlative coefficients $(x)$ within the following ranges: $0.439<\mathbf{x} ; 0.440 \leq \mathbf{x} \leq 0.559$; and $0.560 \leq \mathbf{x} \leq 1.000$, were interpreted as non-correlatives, partial correlatives and strong correlatives, respectively. The level of confidence for partial correlations was chosen at: $\leq 95 \%$ (i.e. less than $5 \%$ error or significance level of about 0.05 , while the confidence level for strong correlation was selected at: $\leq 99 \%$ which is less than $1 \%$ error or 0.01 level of significance (Ukpai and Okogbue 2017). Strong correlation between heavy metals, $\mathrm{Pb}$ and $\mathrm{Zn}$ at 0.961 (see Table 3), that is at 96\% showed their association as $\mathrm{Pb}-\mathrm{Zn}$ Ore. Strong correlation between $\mathrm{Pb}-\mathrm{Zn}$ and anions except $\mathrm{HCO}_{3}$ indicates that process relating to weathering of the calcareous shale bedrock is not associated with dissolution of trace metals. Apart from chloride suspectedly contributed mainly from influx of connate water, the evolutions of anions like $\mathrm{SO}_{4}{ }^{2-}$ and heavy metals such as $\mathrm{Pb}$ and $\mathrm{Zn}$ have been associated with point source loading from mine water via anthropogenic (or mining) activities. This assertion concurs with the fact that mine water releases heavy metals (Blowes et al. 2003) and sulphate ions by the oxidation of sulphur (Li et al. 2018). In contrast, $\mathrm{HCO}_{3}$ evolved from non-point sources through 


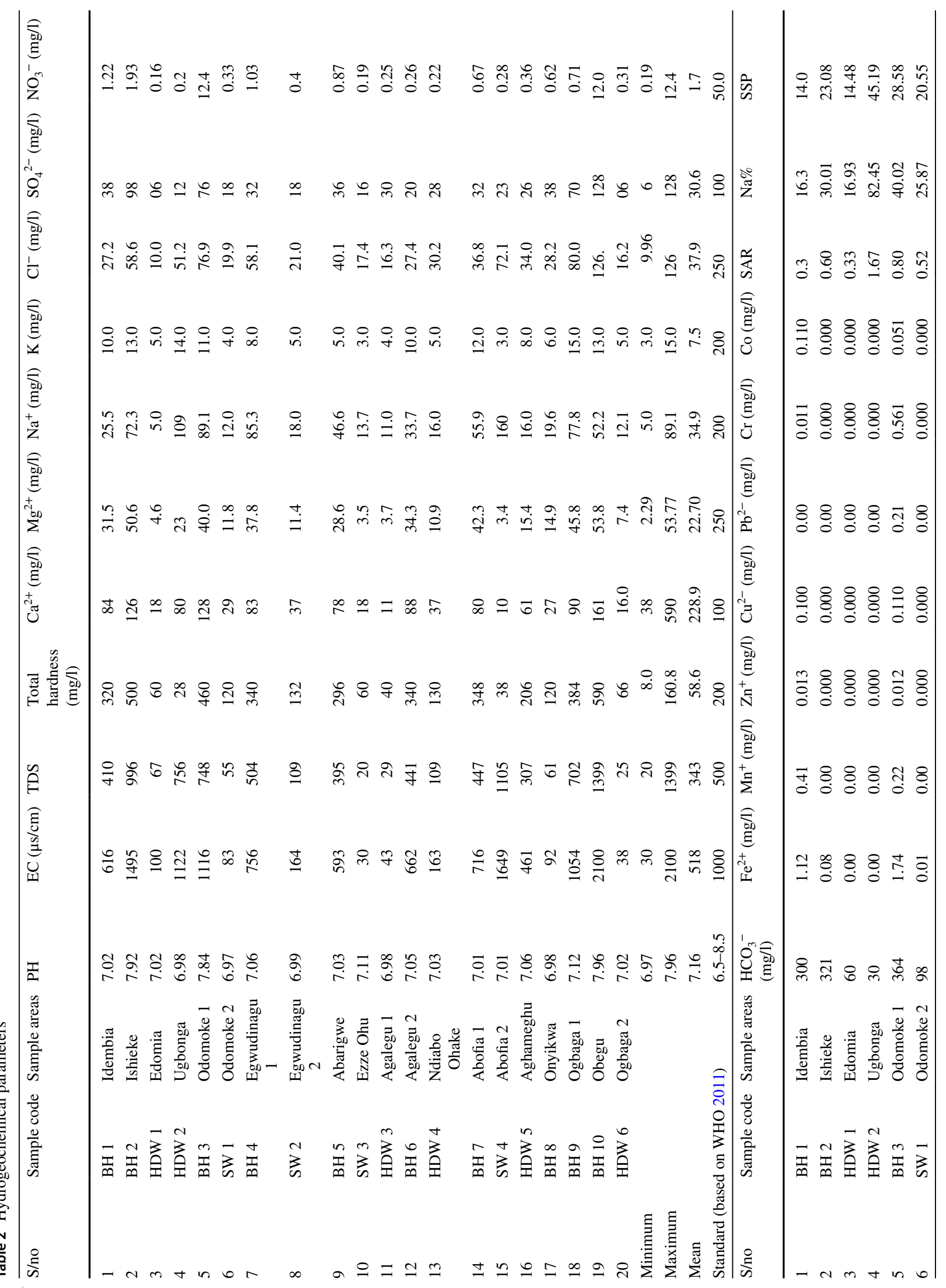




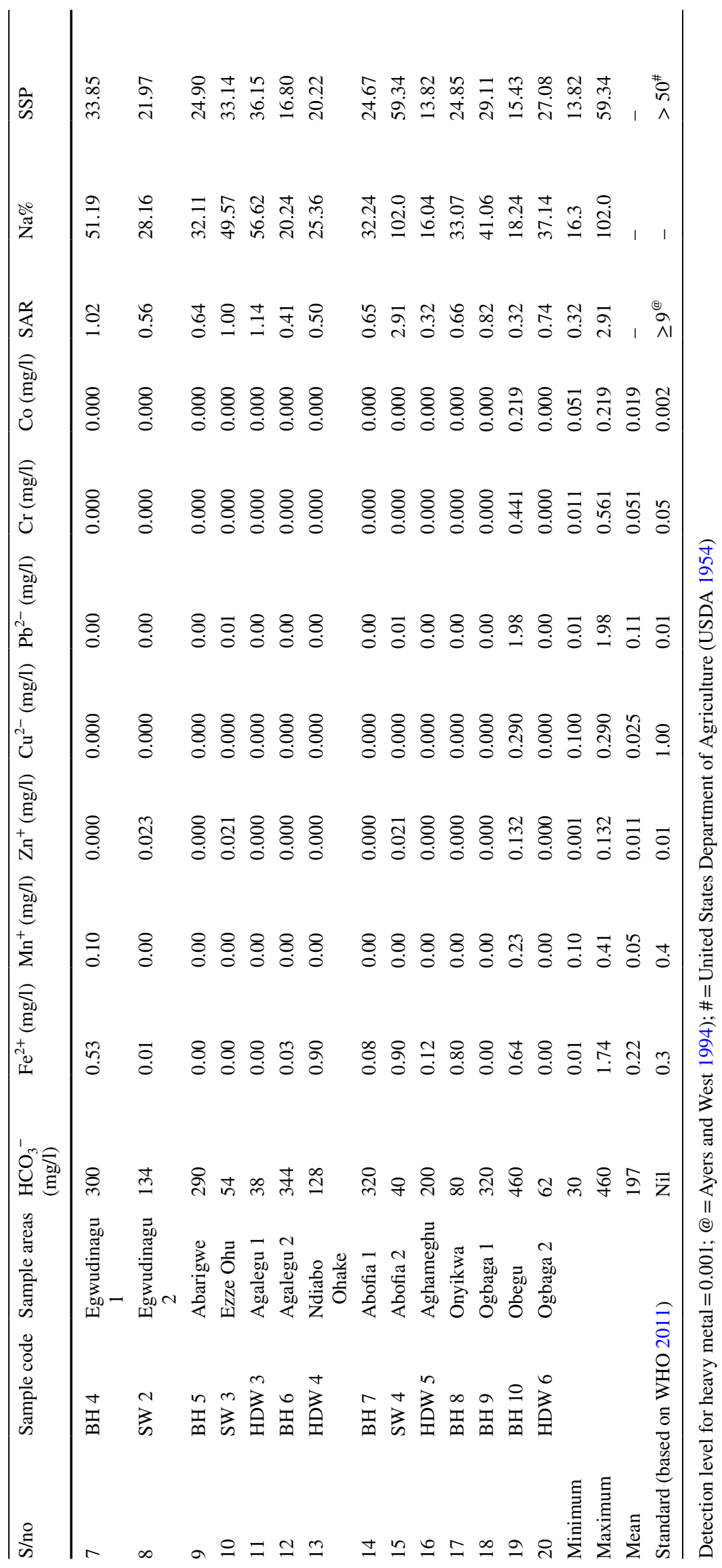




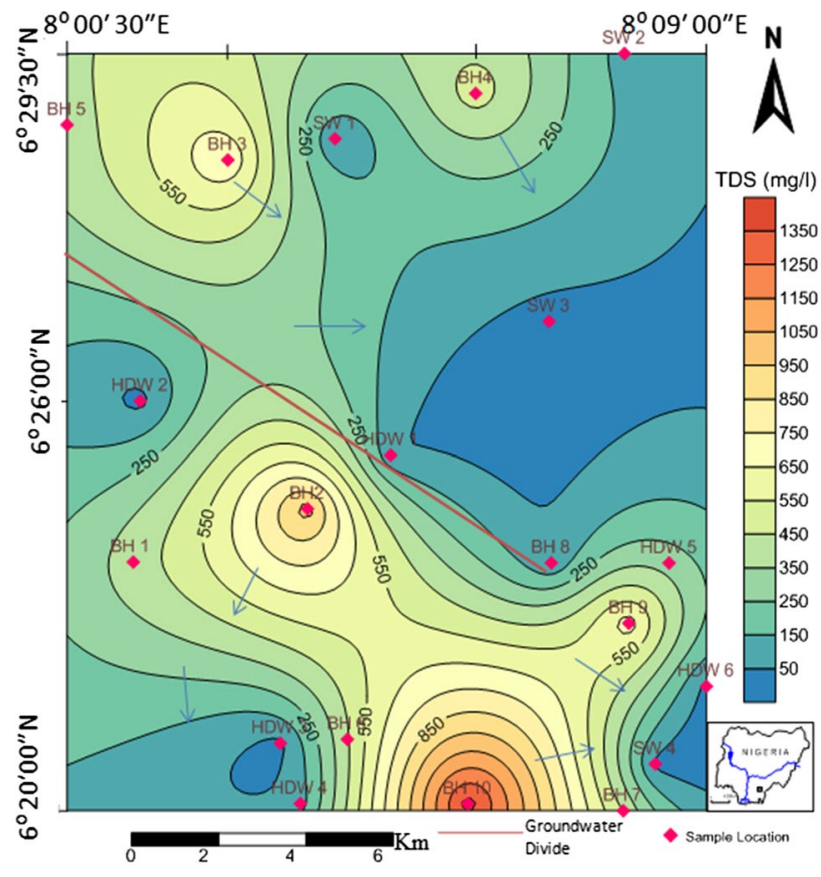

Fig. 7 Map showing dispersion trend of total dissolved solutes (TDS). Note: NW-SE-trending line indicates the groundwater divide

natural (geogenic) interaction of precipitation water with the calcareous sediments (Eq. 5).

\section{Evolutional environments: analysis of the hydrogeochemical facies}

Subdivisions of diamond portion of trilinear graph (Freeze and Cherry 1979) into eight portions (Ukpai et al. 2016) were separately marked as: A, B, C, D, E, F, G and $\mathrm{H}$ (Fig. 9). Each portion represents a compositional category of cations and anions concentrations, described by Kehew (2001) as a hydrogeochemical facie. Four hydrogeochemical facies, namely $\mathbf{A}, \mathbf{E}, \mathbf{F}$ and $\mathbf{G}$, for the respective $\mathrm{Ca}-\mathrm{HCO}_{3}$ facie, $\mathrm{Ca}-\mathrm{Mg}-\mathrm{HCO}_{3}-\mathrm{SO}_{4}$ facie, $\mathrm{Na}-\mathrm{Ca}-\mathrm{HCO}_{3}-\mathrm{Cl}-\mathrm{SO}_{4}$ facie and $\mathrm{Na}-\mathrm{Cl}-\mathrm{HCO}_{3}$ facie, were identified within the studied watershed. In hydrochemical sequence of anion mobility, $\mathrm{HCO}_{3}$ predominates at recharge zone, $\mathrm{SO}_{4}{ }^{2-}$ dominates at intermediate zone, while $\mathrm{Cl}^{-}$is the most abundant anion at discharge zone or even in connate water. For cations, Fetter (2007) reported dominance of $\mathrm{Ca}$ and $\mathrm{Mg}$ at recharge zone, whereas the dominance of $\mathrm{Na}$ and $\mathrm{Cl}$ depicts connate water.

Facie A comprises BH 6 (Agalegu area 2), whereas BH 1 (Idemia area) and BH 7 (Abofia area 1) overlapped between facies $\mathbf{A}$ and $\mathbf{E}$. The facie type $\mathbf{A}$ is dominated by hard water genetic ions like $\mathrm{Ca}^{2+}$ and $\mathrm{HCO}_{3}{ }^{-}$which characterized meteoric water with short residence time. The facie appears to have transited from weathered portion of the bedrocks, most of which evolved to form facie type $\mathbf{E}$. The facie $\mathbf{E}$ is massive, constituting about $75 \%$ of water resources sampled,

$\mathrm{CaCO}_{3}+\mathrm{H}_{2} \mathrm{CO}_{3} \rightarrow \mathrm{Ca}^{2+}+2 \mathrm{HCO}_{3}^{-}$

$($ Calcareous bedrock $)+($ rainfall $) \rightarrow($ calcium ion $)+($ bicarbonate ion $)$

Equation 5 is valid because $\mathrm{HCO}_{3}{ }^{-}$is the dominant form of carbonate in water resource system of $\mathrm{pH}$ range from 6.5 to 9.0 (Freeze and Cherry 1979) being typified in the watershed. Evolution of $\mathrm{Ca}^{2+}$ and $\mathrm{HCO}_{3}{ }^{-}$from Eq. (5) inflicted hardness on the water supplies (Tables 3, 4). Influence of precipitation on the weathering of bedrock was generally deduced from Gibbs graph. As seen in the graph, assemblage of representative samples (i.e. factors) between rock weathering and precipitation segments (Fig. 8) signified chemical dilution of rock minerals by influence of precipitation (Okogbue and Ukpai 2013). It means that percolation of precipitation (rain) water resulted in the chemical weathering via rock dissolutions (Fig. 9). The factors aligning along diagonal axis marked with 1,5 and 9 in the central portion of the Durov graph (see Fig. 5) denote dissolution process (Lloyd and Heathcote 1985). This geochemical process released groups of ionic concentrations that injected the major hydrogeochemical facies in the water resources of the watershed (Fig. 10). including SW 3 that overlapped with facie $\mathbf{F}$ (see Fig. 9). These samples cluster within hydrological zone mainly characterized by the composition of $\mathrm{Ca}^{2+}, \mathrm{Mg}^{2+}$ and $\mathrm{HCO}_{3}{ }^{-}$. Because of the enrichment of these ions in the facie, it is safe to describe it as hard water type. This hard nature is important parameter for water users (Rubenowitz-Lundin and Hiscock 2013). Minor presence of SO4 ${ }^{2-}$ implies the facie has resided relatively long within the water table as it evolved further away from recharged zone. The facie (or water type) $\mathbf{E}$ evolved to facie $\mathbf{F}$ ( $\mathrm{Na}-\mathrm{Ca}-\mathrm{HCO}_{3}-\mathrm{Cl}-\mathrm{SO}_{4}$ ) by loosing magnesium ion $\left(\mathrm{Mg}^{2+}\right)$ for sodium ion $\left(\mathrm{Na}^{+}\right)$via ion exchange mechanism, such that in milli-equivalence capacity, $\mathrm{Na}^{+}$dominated the cation concentrations, while content of $\mathrm{Cl}^{-}$surpassed $\mathrm{SO}_{4}{ }^{2-}$. So, the hard water trait is gradually diminishing in facie $\mathbf{F}$ as it is getting enriched with saline characteristic $\mathrm{Na}$ and $\mathrm{Cl}$ ions. For this reason, this facie can be described as water type from mix hydrological zone where groundwater of meteoric origin flushes connate water surging from deeper subsurface zone. The facie dominated areas at the topographic elevation where the water table apparently outcropped as it configured towards the surface 


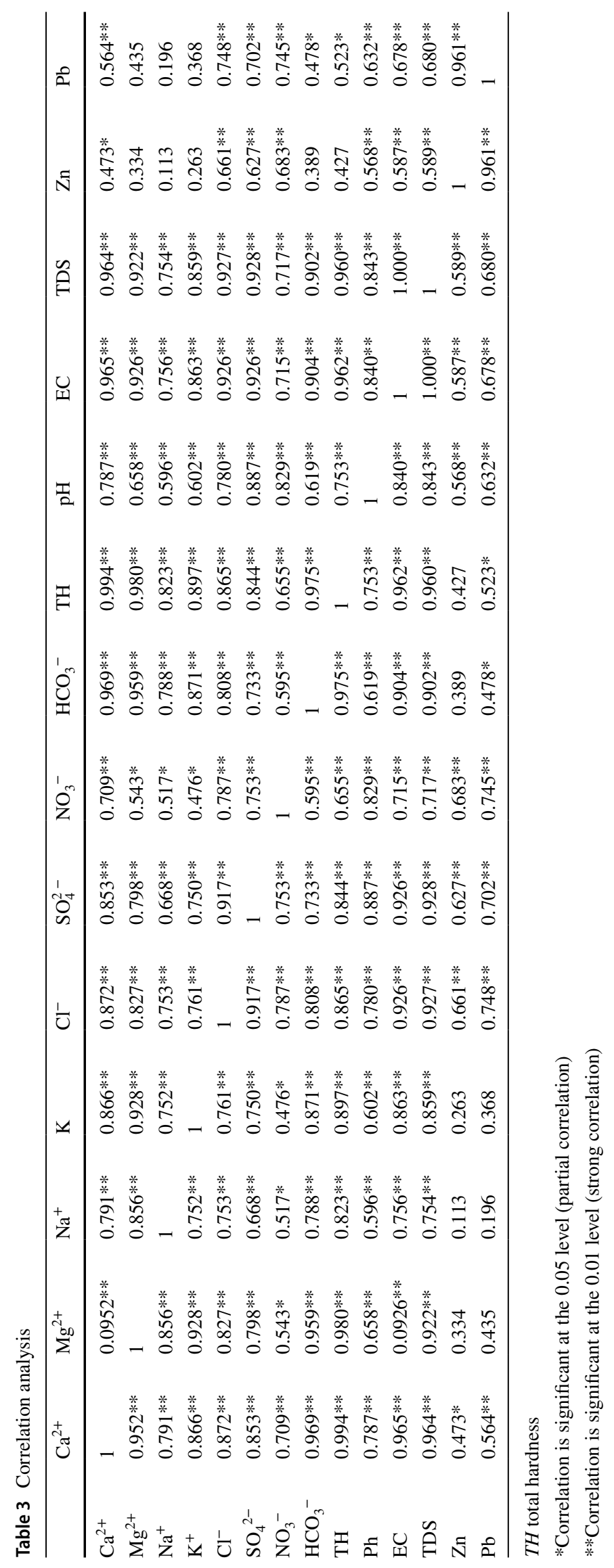


Table 4 Classification of hardness, EC, TDS and the affected samples

\begin{tabular}{|c|c|c|c|c|c|c|c|c|c|}
\hline \multicolumn{3}{|c|}{ Water hardness (mg/l) } & \multicolumn{3}{|l|}{ TDS (mg/l) } & \multicolumn{4}{|c|}{ Electrical conductivity $(\mu \mathrm{s} / \mathrm{cm})$} \\
\hline Class & Remark & $\begin{array}{l}\text { Affected } \\
\text { samples }\end{array}$ & Class & Remark & $\begin{array}{l}\text { Affected } \\
\text { samples }\end{array}$ & Class & Remark & $\begin{array}{l}\text { Affected } \\
\text { samples }\end{array}$ & Interpretations \\
\hline$<75$ & Soft & $\begin{array}{l}\text { HDW 1, } \\
\text { HDW 2, } \\
\text { HDW 3, } \\
\text { SW 4, SW } \\
\text { 3, HDW } 6\end{array}$ & No hazard & $<500$ & $\begin{array}{l}\text { BH 1, HDW } \\
\text { 1, SW 1, } \\
\text { SW 2, BH } \\
\text { 5, SW } \\
\text { 3, HDW } \\
\text { 3, BH } \\
\text { 6, HDW } \\
\text { 4, BH 7, } \\
\text { HDW 5, } \\
\text { BH 8, } \\
\text { HDW } 6\end{array}$ & $<250$ & $\begin{array}{l}\text { Excellent } \\
\text { (C1) }\end{array}$ & $\begin{array}{l}\text { HDW 1, } \\
\text { SW 1, SW } \\
2, \text { SW } \\
3, \text { HDW } \\
\text { 3, HDW } \\
\text { 4, BH 8, } \\
\text { HDW } 6\end{array}$ & $\begin{array}{l}\text { Water that is } \\
\text { very safe for } \\
\text { all crops }\end{array}$ \\
\hline $75-150$ & $\begin{array}{l}\text { Moderately } \\
\text { hard }\end{array}$ & $\begin{array}{l}\text { SW 1, SW } \\
\text { 2, HDW 4, } \\
\text { BH } 8\end{array}$ & $\begin{array}{c}\text { Slightly } \\
\text { hazard }\end{array}$ & $500-1000$ & $\begin{array}{c}\text { BH 2, HDW } \\
2, \text { BH 3, } \\
\text { BH 4, } \\
\text { BH } 9\end{array}$ & $250-750$ & Good (C2) & $\begin{array}{c}\text { BH 1, BH 5, } \\
\text { BH 6, BH } \\
7, \text { HDW } 5\end{array}$ & $\begin{array}{l}\text { Detrimental } \\
\text { effect may } \\
\text { not be easily } \\
\text { noticed on } \\
\text { crops }\end{array}$ \\
\hline $150-300$ & Hard & HDW 5 & Hazard & $1000-2000$ & SW 4, BH 10 & $750-2250$ & $\begin{array}{l}\text { Doubtful } \\
\text { (C3) }\end{array}$ & $\begin{array}{c}\text { BH 2, BH } \\
3, \text { BH 4, } \\
\text { BH 9, BH } \\
\text { 10, SW 4, } \\
\text { HDW 2, }\end{array}$ & $\begin{array}{l}\text { Adverse; } \\
\text { except on } \\
\text { salt tolerated } \\
\text { crops }\end{array}$ \\
\hline$>300$ & Very hard & $\begin{array}{c}\text { BH 1, BH 2, } \\
\text { BH 3, BH } \\
4, \text { BH 5, } \\
\text { BH 6, BH } \\
7, \text { BH 9, } \\
\text { BH } 10\end{array}$ & Severe & $>2000$ & NIL & $>2250$ & $\begin{array}{l}\text { Unsuitable } \\
\text { (C4) }\end{array}$ & NIL & $\begin{array}{l}\text { Harmful to all } \\
\text { crops }\end{array}$ \\
\hline
\end{tabular}
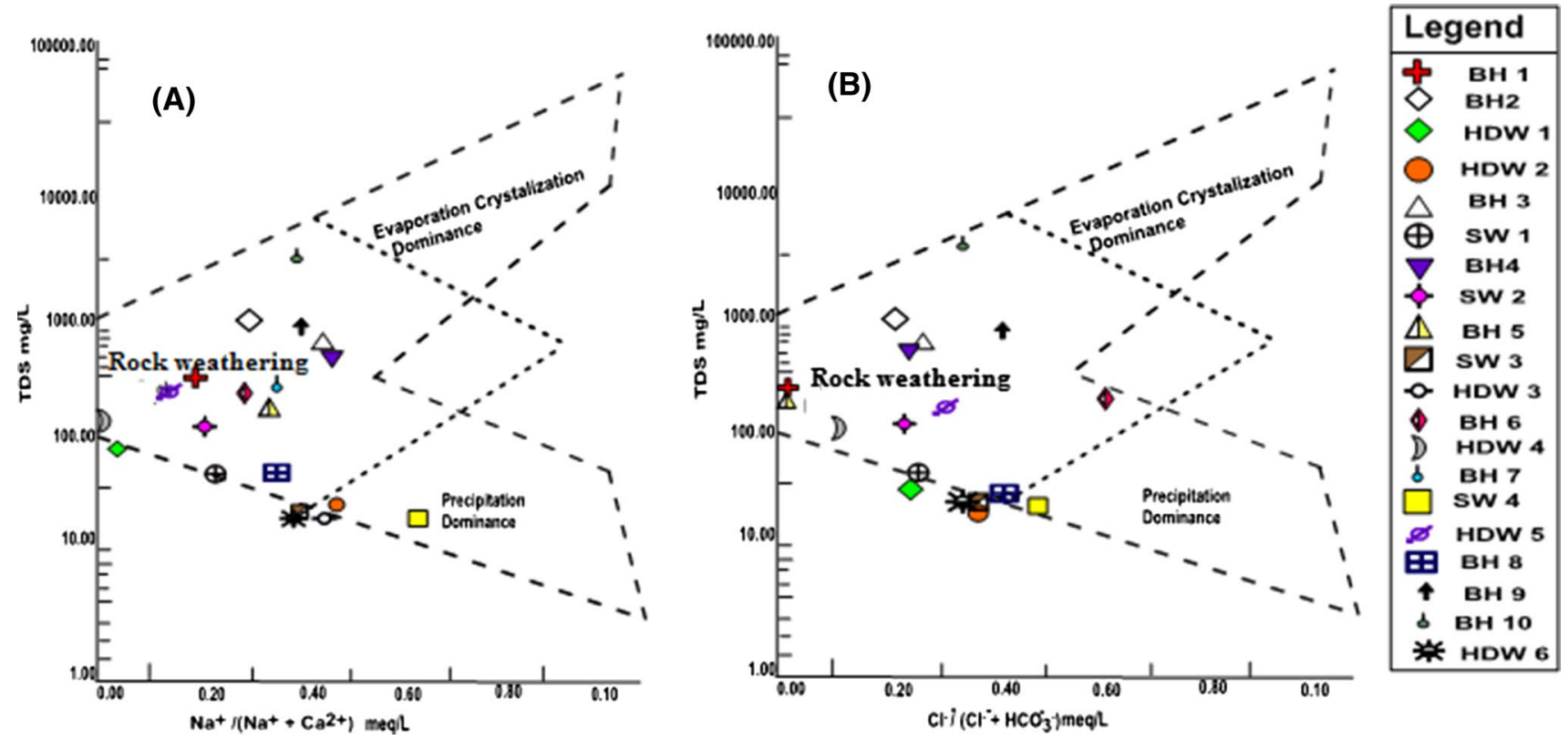

Fig. 8 Gibbs graphs showing (influence of precipitation on rock weathering as) the major primary geochemical process 


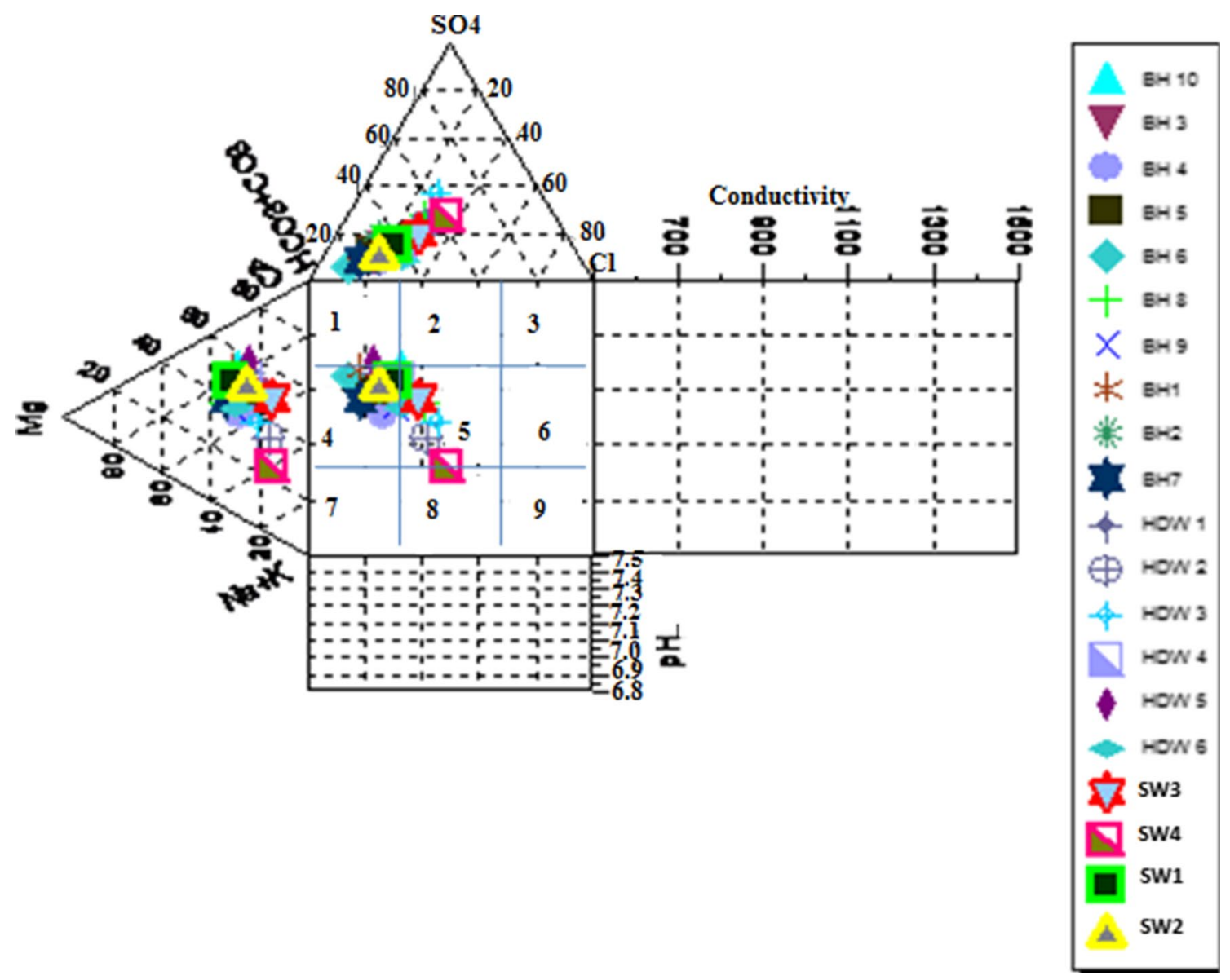

Fig. 9 Durov diagram showing (dissolution as) the secondary geochemical process

to discharge into the fluvial system around Ugbonga (HDW 2) and Onyikwa for BH 8 (see Fig. 9). The occurrence of this facie in these areas has further proved groundwater discharges at the elevated landform axes and hence formed river catchments (see Fig. 1) at both sides of the groundwater divide (see Fig. 6). The salinized groundwater discharges, and in addition to solutes in mine water being drained by run-off, increased the TDS concentrations at downgradient part of Ebonyi River and hence fall into facie type G. Dissolved solutes, mainly $\mathrm{Na}^{+}$and $\mathrm{Cl}^{-}$predominated the hydrogeochemical facie $\mathbf{G}\left(\mathrm{Na}-\mathrm{Cl}-\mathrm{HCO}_{3}\right)$ which depicts water type with connate background. The facie type $\mathbf{G}$ comprises SW 4 (Abofia axis of Ebonyi River), and with the overlap of the facie type $\mathbf{F}$ represented in HDW 2 (see Fig. 9), it seemed that dominance of facie $\mathbf{G}$ at the lower course of Ebonyi River within the watershed was by the aggregation or collections of typical facie $\mathbf{F}$ that discharged to the river.

The identification of saline facie $\mathbf{G}$ thus distinguished saltwater of connate background at Abofia (SW 4) and Ugbonga (HDW 2) areas from salinized water of meteoric background at Ishieke (BH 2) and Obegu (BH 10) areas, all with concentrations of TDS greater than $1000 \pm 250 \mathrm{mg} / \mathrm{l}$ (see Table 2). The high TDS in deep groundwater representative boreholes typified meteoric water with long residence time and interpreted in the hydrogeochemical facie E. Also, those of connate background at the near-surface [shallow groundwater from hand-dug well (HDW)] and surface [i.e. surface water (SW)] regimes that constitute facie $\mathbf{G}$ are typical of localized salinization of freshwater system by saline connate water that migrated from deeper subsurface. The local migration of connate water agrees with the previous literature in Asu River Group of lower Benue Trough (Ukpai and Okogbue 2017; Tijani et al. 1996; Uma and Lohnert 1992). The sodic facies $\mathbf{F}$ and $\mathbf{G}$ exchange $\mathrm{Ca}^{2+}$ that flocculated the matrix of weathered bedrock with inherent $\mathrm{Na}^{+}$ to cause dispersion of the rock aggregates. Levy and Shainberg (2005) noticed that deflocculation of soil seals the permeability capacity. Predictably, this minimized the rate of infiltration of rainfalls (Horneck et al. 2007) into the water table, thereby hampering the occurrences of groundwater in economic quantity into the local aquifers around the region. 


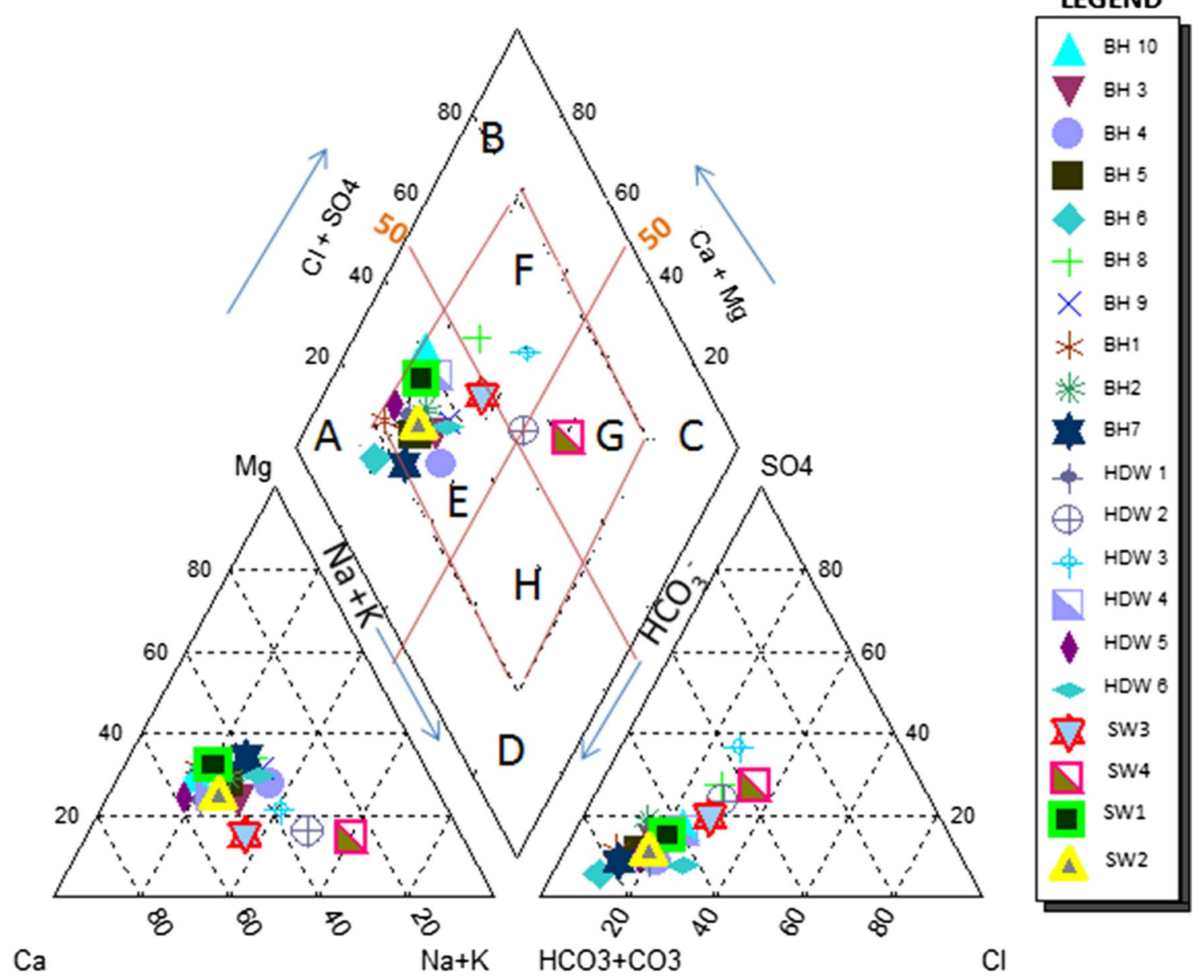

Fig. 10 Piper trilinear graph showing hydrochemical facies and the evolutionary origins

\section{Hazard analyses in the economic sectors}

\section{Industrial and domestic economy}

Elevated levels of total hardness (TDS) and pollution of some heavy metals at various places (see Table 2) have influenced the potential of the water resources for industrial and domestic supplies. Contents of the TDS are greater than aesthetic limit of $500 \mathrm{mg} / \mathrm{l}$ at some parts of the watershed (Table 4). Dissolved $\mathrm{Fe}$ and some heavy metals exceeded the permissable limits in places (see Table 2) and hence contributed to the bioavailable portion of the TDS. Blotting of brownish colouration on food cooked with water supplied from some boreholes in the area is relatively attributed to the presence of dissolved iron $(\mathrm{Fe})$ in toxic level. Apart from loosing appetite, cooked food, particularly the "leftover", is mostly wasted as it cannot be preserved under such non-aesthetic outlook. It is suspected that at cooking temperature, diffusion space for the dissolved Fe decreases; as such, the ion diffuses into the food stuff. Okogbue and Ukpai (2013) earlier reported metal poisoning among the people of Abakaliki Province and traced it to mine effluent that released heavy metal plumes to the water resources. It is thus safe to establish that metals, particularly those analysed like $\mathrm{Fe}, \mathrm{Mn}, \mathrm{Zn}, \mathrm{Co}, \mathrm{Pb}$ and $\mathrm{Cr}$, are exposed to biota of the region, by either intake of the affected water supply or consumption of food poisoned by the metals.

Generally, about $70 \%$ of the water resources have total hardness greater than $100 \mathrm{mg} / \mathrm{l}$ (Table 2), comprising 50\% from deep groundwater (boreholes), $10 \%$ from shallow groundwater (dug wells) and $10 \%$ from the surface water regime. Ukpai et al. (2017) had related hardness of water to health damages, such as atopic dermatitis or eczema on human skin through bathing. Miyake et al. (2004) reported that skin damages relating to hardness of water could be more prevalent in children than adults. It means therefore that soft or young skins are vulnerable to inflammations due to the use of hard water. Irrespective of the economic burdens related to utilization of hard water (Sultana et al. 2018) in laundry and domestic services, it protects metal pipes from corrosion and hence prevents concentrations of heavy metals into pipe-borne water supply circulated to the populace of Abakaliki municipal. The increase in temperature due to global 
warming (Akpodiogaga and Ovuyovwiroye 2010), however, affects slight rise in temperature of water resources, thereby subjecting those characterized by hardness to precipitation (scaling) and subsequent encrustation and clogging of water gadgets and fittings. Thus, it is safe to attribute clogging of household water fittings, as well as the encrusting nature of metal (bathing) buckets and kitchen utensils like kettles to distributions of water supplies from facies $\mathbf{A}$ and $\mathbf{E}$. In the same way, traditional failures of boreholes in the area have even been noted and correlated with prevalence of the hydrogeochemical facie $\mathbf{E}$. This is because water supplied from this facie caused the encrustation of ions, which clogged water passage fittings, including slot sizes of the borehole screens, resulting in the mechanical failure.

\section{Agricultural economics}

The salinity hazard was evaluated based on the configuration of TDS and EC (Hussain et al. 2010). Salt precipitated by the migrated saline water at the soil zone has direct impacts pertaining building of osmotic pressure between the soil water and plant roots (Munns et al. 2002). The pressure reverses movement of water from plants to the soil and hence results in physiological drought condition (Kelvin 2005). This condition drains water from food crops in such a manner that cause growth inhibition and possible death (Fujiyama and Magara 2002). Aquatic biota can also be affected by the salinity hazard, especially at TDS greater than $1000 \mathrm{mg} / \mathrm{l}$ (Nielsen et al. 2003). This must be the case of aquatic biomass at the lower course of Ebonyi River around Abofia area 2 (see Fig. 1). It means that water supplies either from this side of the river or even from some boreholes like $\mathrm{BH} 10$ cannot be used in aquaculture.

Results of sodium adsorption ratio (SAR), sodium percentage (Na\%) and soluble sodium percentage (SSP) (see Table 2) were deduced from Eqs. 1 to 3 for the analysis of sodium hazard. As given in the table, SAR ranges from 0.32 to 2.91. According to Fetter (2007), the range of SAR from 2 to 10 can cause minor injury to food crops. SAR values from 3 to 9 lie between low and high, which is medium class (Ayers and West 1994) and can cause slight injuries to food crops (FAO 1985). As given in Table 2, lower limits of these ranges were identified in sample 15 (SW 4), representing the lower course of Ebonyi River around Abofia area 2. As given in Table 2, strong sodium percentage ( $\mathrm{Na} \%$ ) up to $82 \%$ and about $100 \%$ was observed in the respective samples 4 (HDW 2) and 15 (SW 4). Graphical correlation of the $\mathrm{Na} \%$ and $\mathrm{EC}$ (Wilcox 1955) showed that while sample HDW 2 (Ugbonga) is somewhat good (Fig. 11), maybe to salt-tolerant crops, it is slightly hazardous in terms of TDS (Table 4). More so, the graph indicates that sample SW 4 (Abofia area 2) falls within permissible doubtful range (Fig. 11), but still hazardous with respect to TDS (Table 4). Yet, in general, the configuration of $\mathrm{EC}(\mu \mathrm{s} / \mathrm{cm})$ showed that the two representative samples and others like $\mathrm{BH} 2-\mathrm{BH} 4$ and $\mathrm{BH} 9-\mathrm{BH} 10$ would have adverse effect except on salt-tolerant crops (Table 4). Water supply from areas represented by these samples must cause soil aggregates to deflocculate and looses its stability via dispersion. Soil dispersion aggravates erosion (Levy and Shainberg 2005) and hence may have contributed to localized losses of agronomic crops.
Fig. 11 Graphical correlation of electrical conductivity and sodium percentage
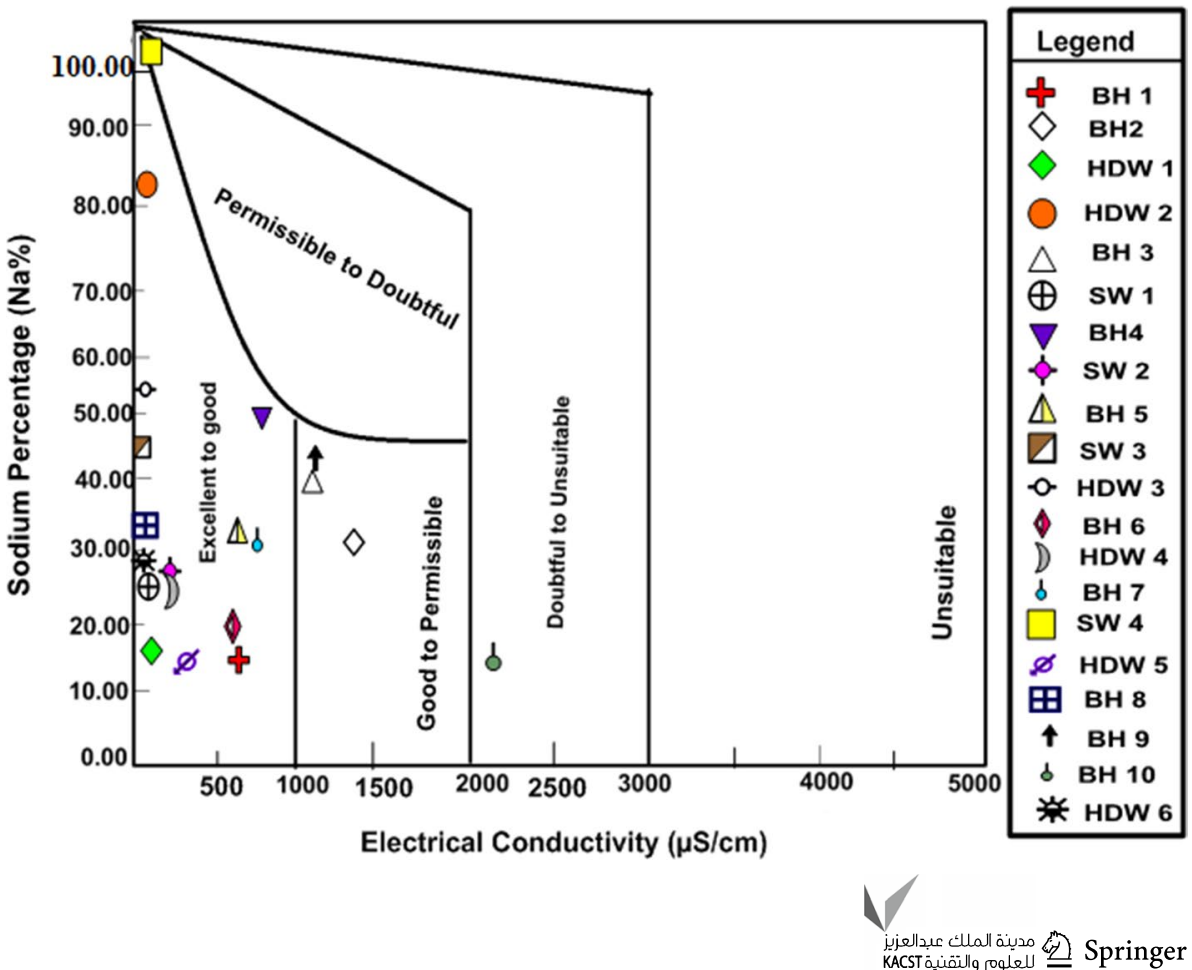
Soluble sodium percentage (SSP) with minimum value of 13.82 and maximum of 59.34 (see Table 2) seems to be moderate; however, the United States Department of Agriculture (USDA 1954) had stipulated water supply with SSP values up to 50 as unacceptable. The Abofia area 2 (SW 4) falling above the limit further confirmed that Ebonyi River at the downstream axis of the watershed is salinized. Thus, decline per capital rice production which resulted in low economic profitability across Ebonyi State (Martins Library 2011) can be attributed to salinization of the rice farms and hence the low output per area around the major rice-producing Abakaliki Province of the state. Typical saline water hampers the mobility of $\mathrm{NO}_{3}$ in soil water and hence could also be attributed to low nitrate in the area, for which the soil lacks $\mathrm{NO}_{3}$-based nitrogen that stimulates growth of rice seedlings.

"Treat before use" programme should be the best approach to rehabilitating water supply from affected portion of the river channelled to farmland for aquaculture and irrigation purposes. For qualitative groundwater supply, "pump and treat" plan should be initiated at the affected boreholes. Routine monitoring and maintenance of the borehole screens in the area will reduce failures and invigorate quantitative water supply to economic sectors. Desalination using gypsum should be part of these treatment schemes, especially at the catchment axis.

\section{Conclusions}

Calcareous bedrock, mainly shales and intercalated sandstones, underlies the studied region, even as the sediments sandwich localized ore deposits. Apart from the mineralization of the bedrocks, migration of connate water was identified in some places and has constituted to elevated concentration of TDS in some places. Anthropogenic (mining) activities and geogenic processes such as chemical weathering, as well as precipitation of salt from connate water regime, are means through which the solutes evolved into the soil zone (weathered bedrock). The weathered layer somewhat interconnecting and dominated by argillaceous silty and sandy shale formed aquitards that transmitted groundwater slowly to various local aquifers underneath, as well as discharged them to fluvial system. By this means, the TDS advected (transported) and has produced varieties of hydrogeochemical facies. Hard water dominated the facies, although limited migration of heavy metals into pipe-borne water supply, but induced negative impacts on the economy of the region, particularly in groundwater development from borehole failures. Other facies evolving from the connate water induced salinity and sodium hazards, especially at the downstream part of the region, and hence exposed farmlands, even those outside the studied watershed to hazards. Seemingly, these hazards have endangered food crops and aquatic biota, leading to economic challenges, particularly in the decreasing tonnage of rice produced and exported from the region in recent times. Except for the remedial approach, water resources at downstream part of the watershed, especially from Ebonyi River, cannot be used for economic activities due to salinization. Generally, the biomass of the region is vulnerable to bioaccumulation of toxins from polluting iron $(\mathrm{Fe})$ and heavy metals: $\mathrm{Pb}, \mathrm{Zn}, \mathrm{Cr}$ and $\mathrm{Co}$. These attributes contributed to the economic burdens of the populace, spanning from metal poisoning from ingestion of polluted food and water, to inadequate potable water supply for the economic activities due to borehole failures. The localized nature of aquifers (formed in isolated fracture zones) across the consolidated sedimentary terrane limited the estimation of migration rate of the dissolved solute pollutants from recharge to discharge zones. Reconstruction of the present and past temperatures of the groundwater, as well as the residence time, were not estimated due to limitations based on lack of equipments that measure noble gas concentrations and the concentration extents of radioactive isotopes of water. This would have assisted in proffering solutions for the management of the groundwater resource of the watershed.

Acknowledgements The authors are indebted to Dr. Ekwe Amobi of Department of geophysics, Alex Ekueme Federal University, Alike Ikwo, Nigeria, for the analysis of geophysical data; Mr. Tijani Aliyu of Hydrogeochemical Laboratory, Ibadan, Nigeria, for geochemical analysis; and Mr. Ugwoke Tochukwu, A.S. of Seimology Department, IDSL and BGP/CNPC, Base Camp, Kolmani 3D BNT prospect, Pindiga, Gombe State, Nigeria, for the statistical analysis. Our sincere appreciation goes to the editorial crew and erudite reviewers of Applied Water Sciences for inestimable contributions that enhanced the worth of the manuscript for public domain.

Funding There are no funding source and no financial or non-financial support with regard to this study.

\section{Compliance with ethical standards}

Conflict of interest The authors declare that they have no conflict of interest.

Open Access This article is licensed under a Creative Commons Attribution 4.0 International License, which permits use, sharing, adaptation, distribution and reproduction in any medium or format, as long as you give appropriate credit to the original author(s) and the source, provide a link to the Creative Commons licence, and indicate if changes were made. The images or other third party material in this article are included in the article's Creative Commons licence, unless indicated otherwise in a credit line to the material. If material is not included in the article's Creative Commons licence and your intended use is not permitted by statutory regulation or exceeds the permitted use, you will need to obtain permission directly from the copyright holder. To view a copy of this licence, visit http://creativecommons.org/licenses/by/4.0/.

\section{Appendix}

See Figs. 12, 13, 14, 15, 16, 17, 18, 19, 20, 21, 22, 23, 24, 25 and Tables 5 and 6. 


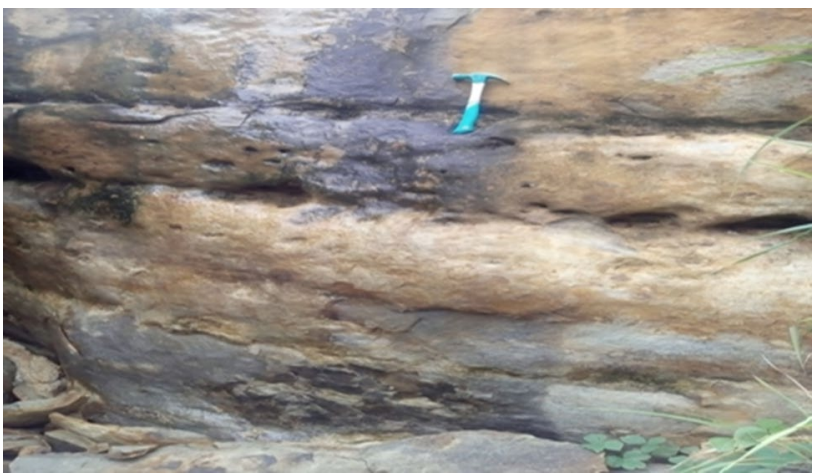

Fig. 12 Calcareous sandstone near Ebonyi State University Permanent site (1 km south of Odomoke area)

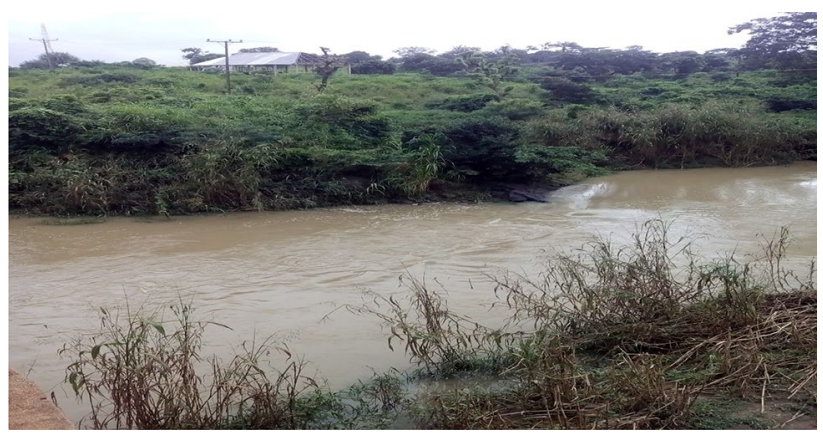

Fig. 14 Ebonyi River at high stage around Ekeberigwe-Egwudinagu axis
Fig. 13 Bedrock: a) mine pit around Odomoke area $1, \mathbf{b}$ minor solution cavity on the calcareous sandstone noodle around Ishieke area, c solution cavity around Ugbonga
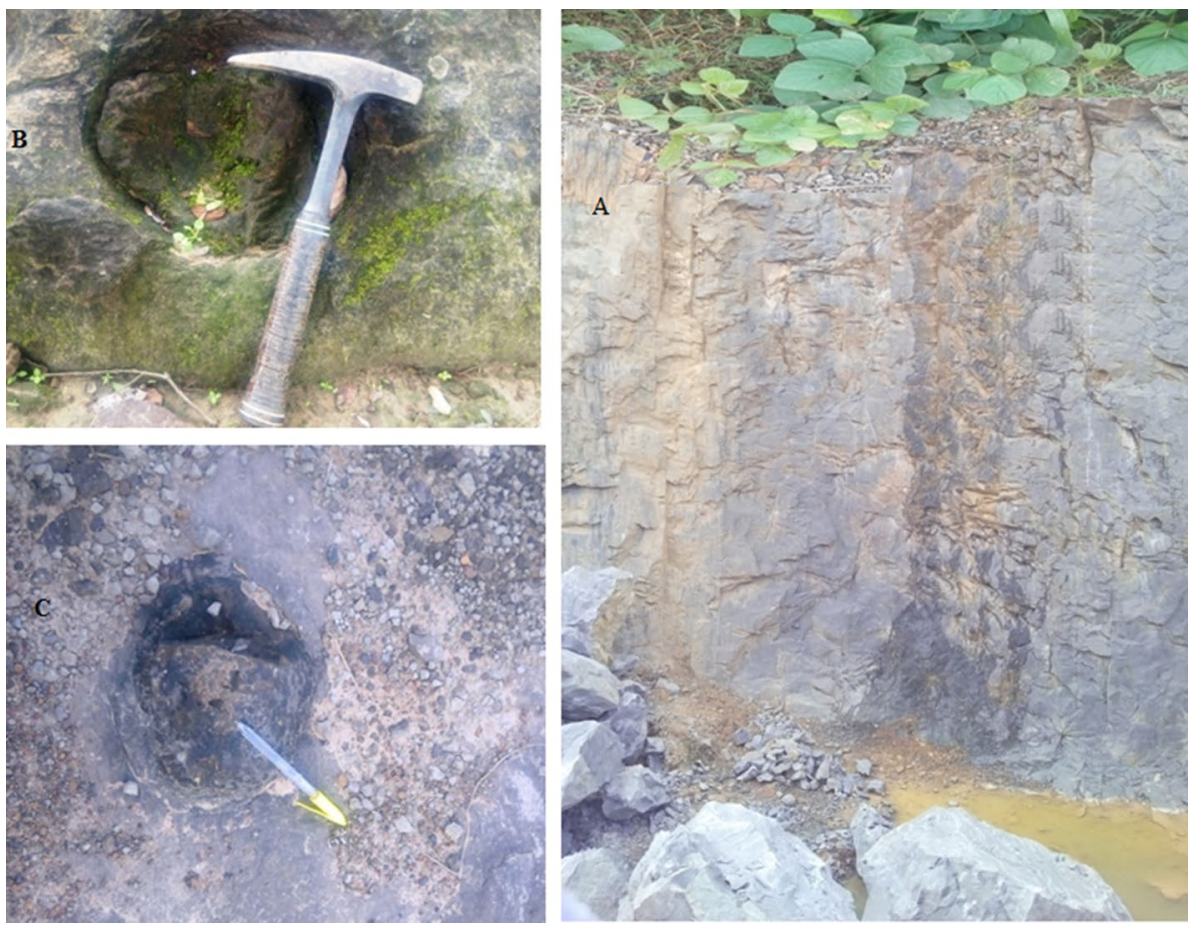


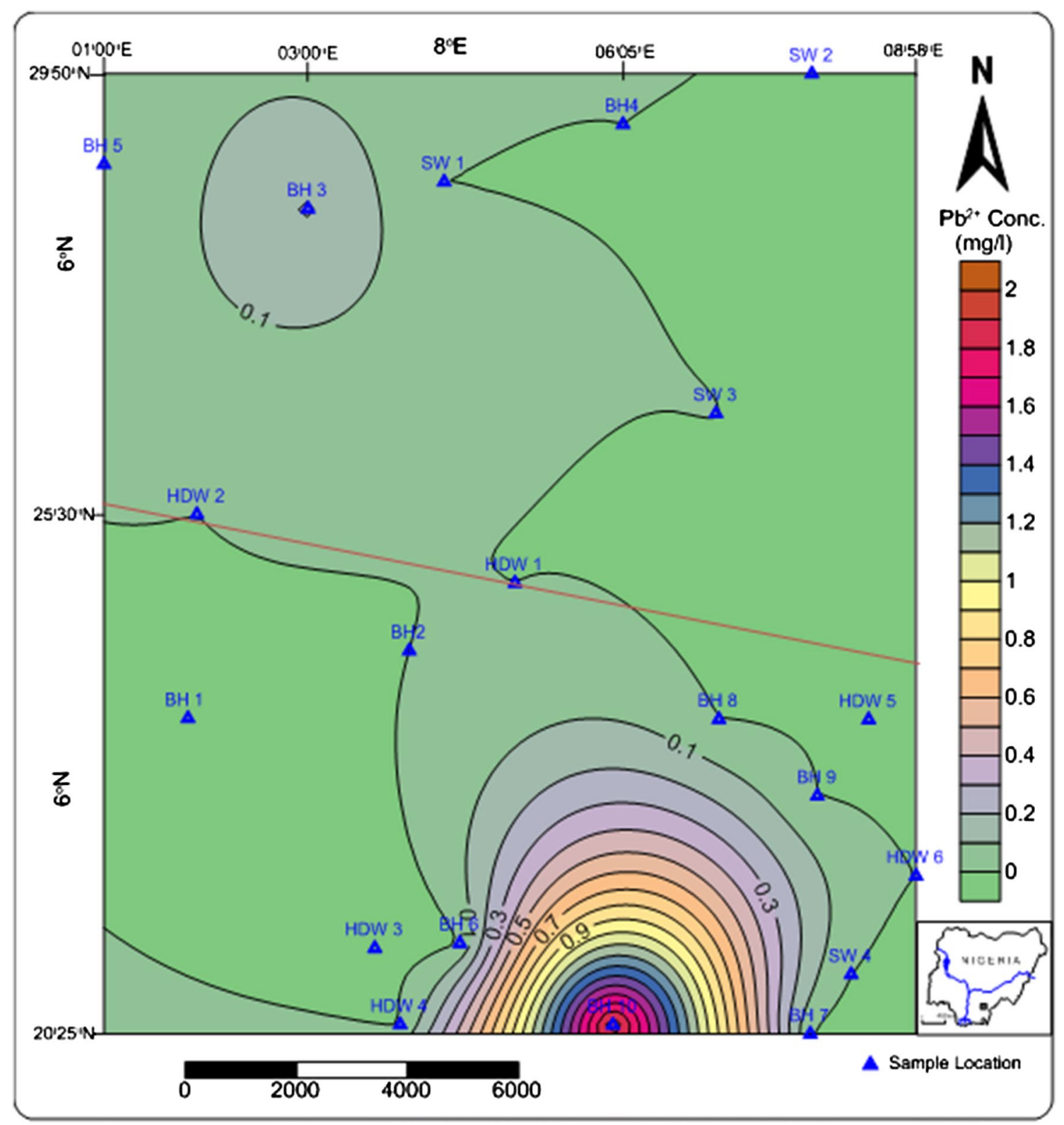

Fig. 15 Map showing dispersion of lead 


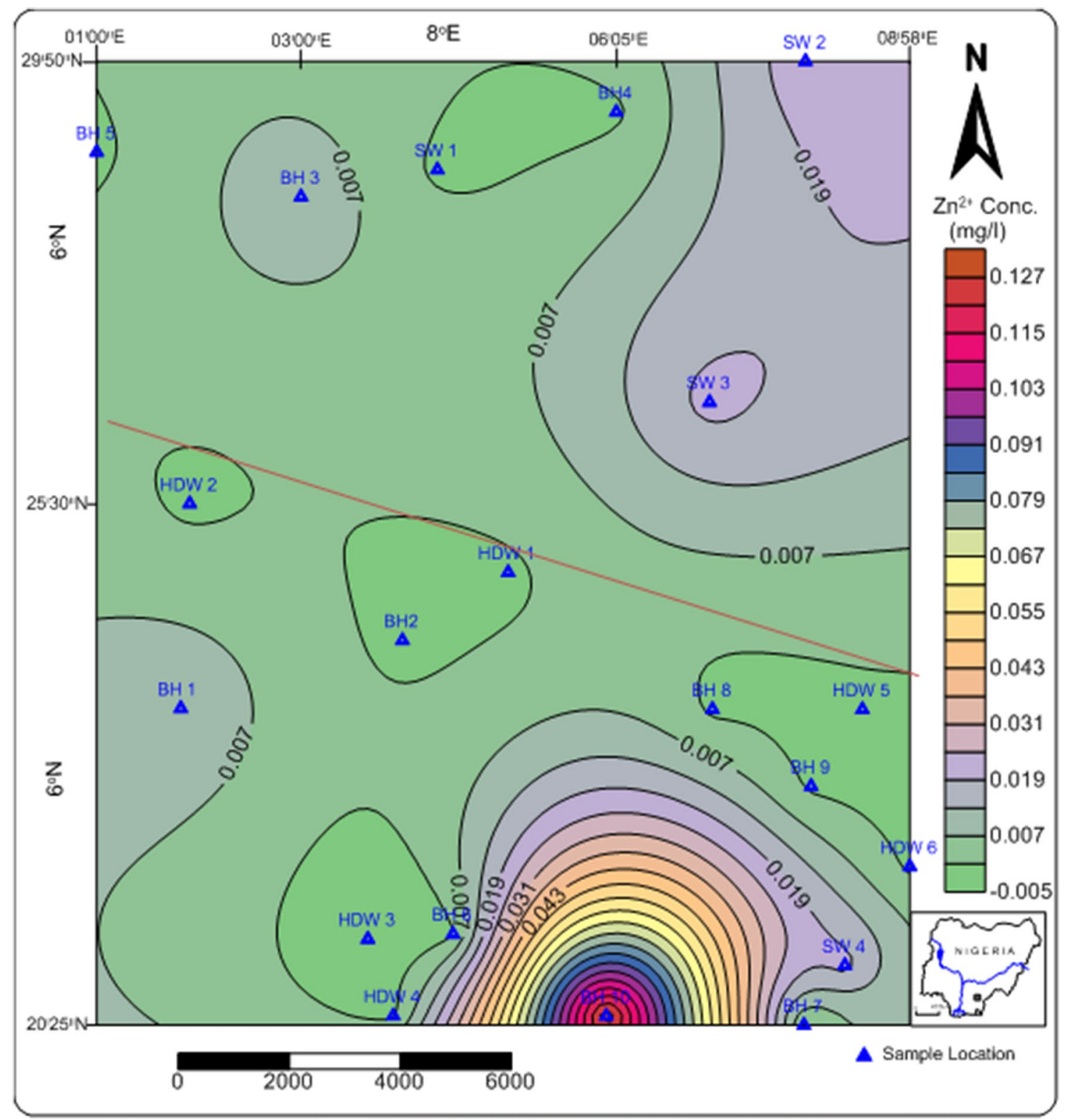

Fig. 16 Map showing dispersion of zinc. Note: Perpendicular line indicates groundwater divide 


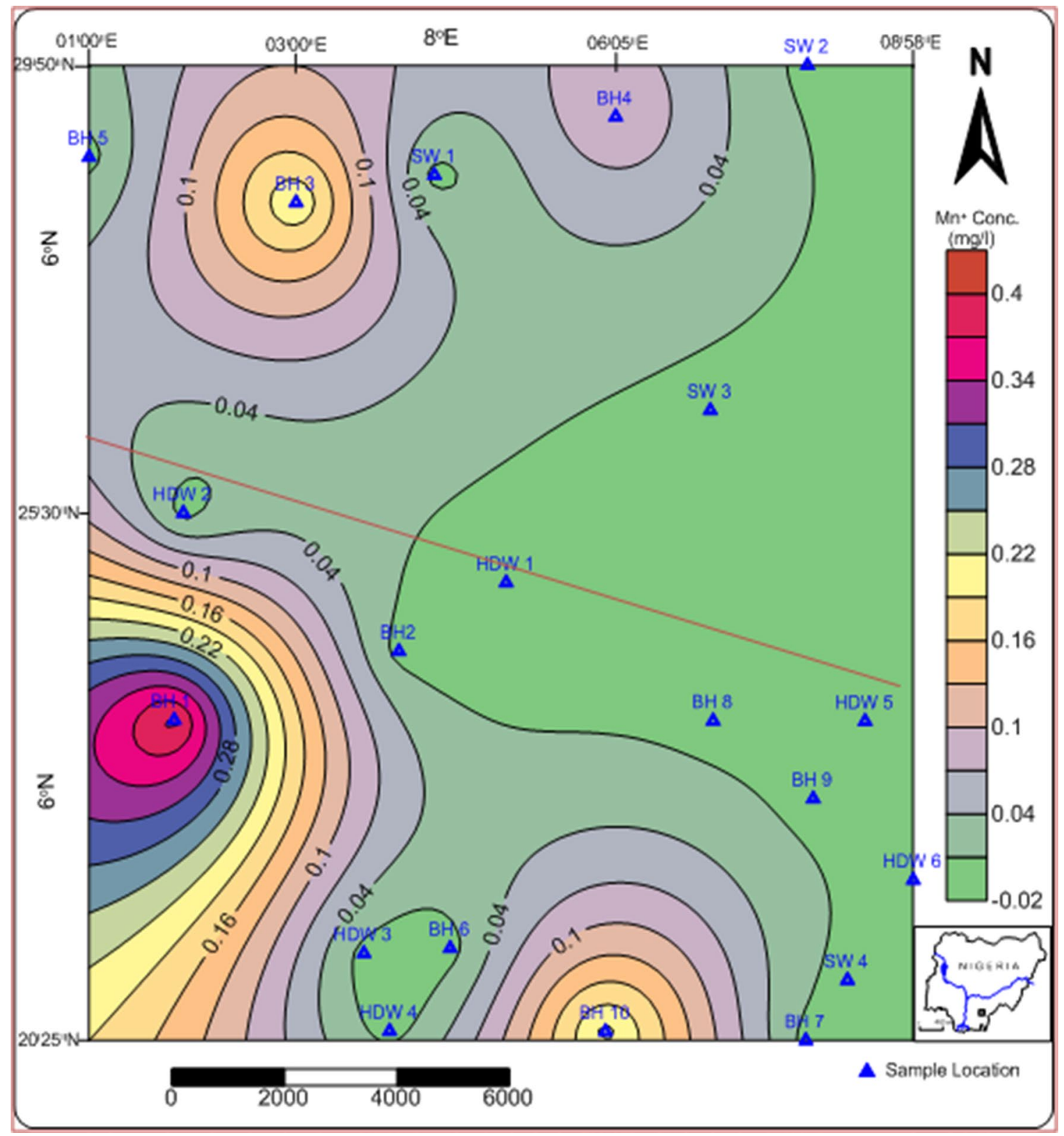

Fig. 17 Map showing dispersion of manganese. Note: Perpendicular line indicates groundwater divide 


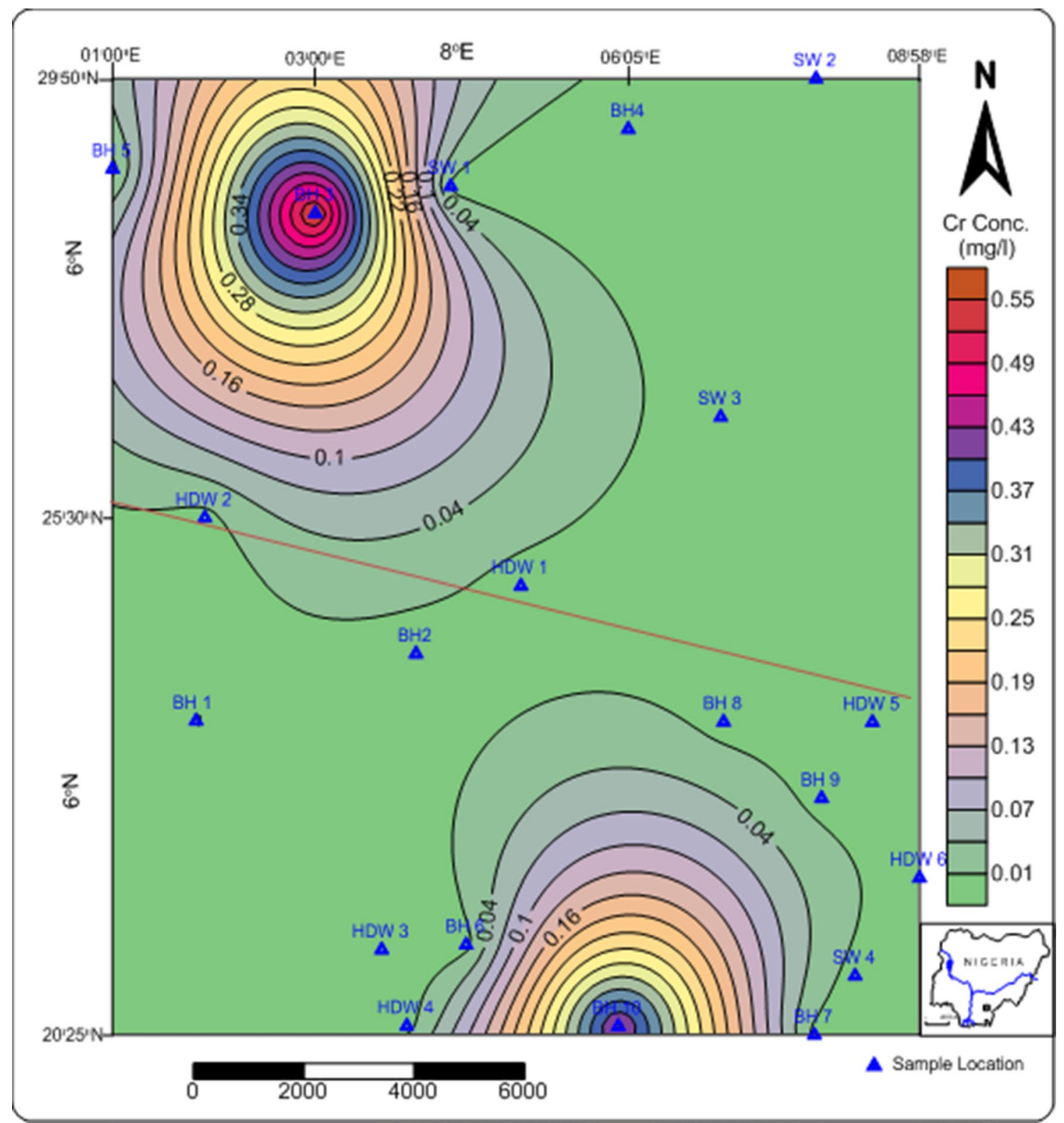

Fig. 18 Map for dispersion of chromium. Note: Perpendicular line indicates groundwater divide 


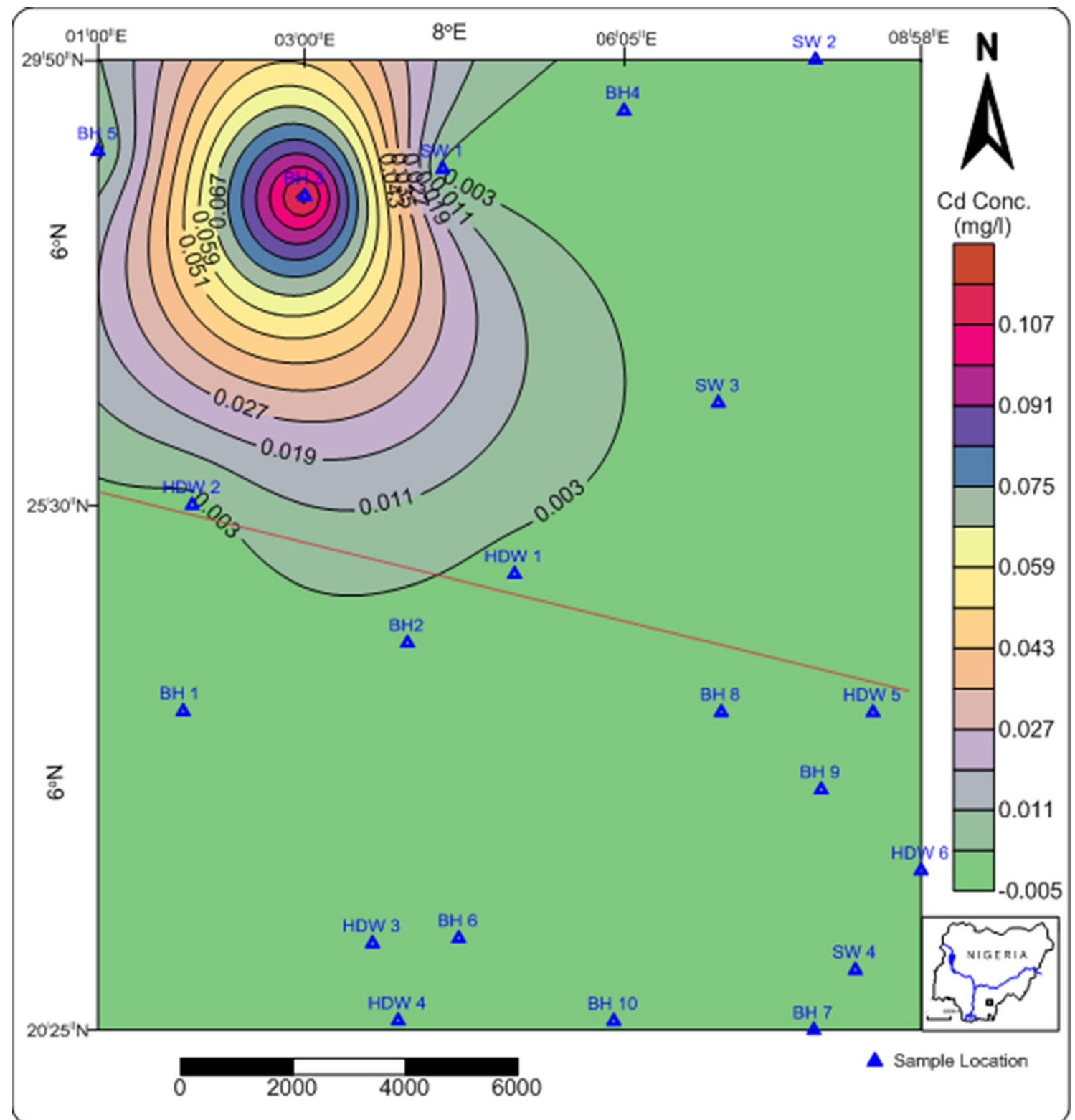

Fig. 19 Dipersion map for cadmium. Note: Perpendicular line indicates groundwater divide 


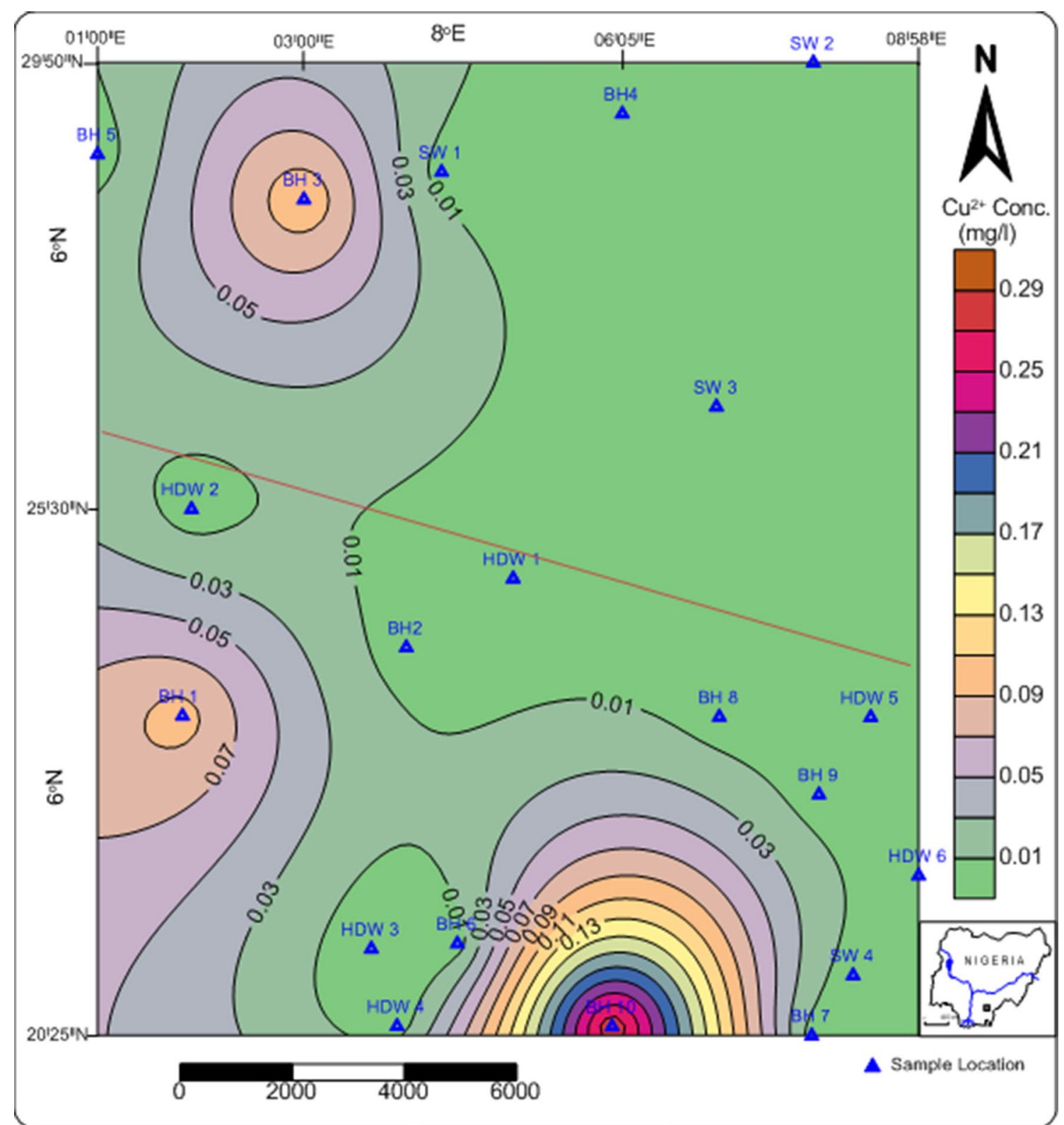

Fig. 20 Map for the dispersion of cobalt. Note: Perpendicular line indicates groundwater divide 


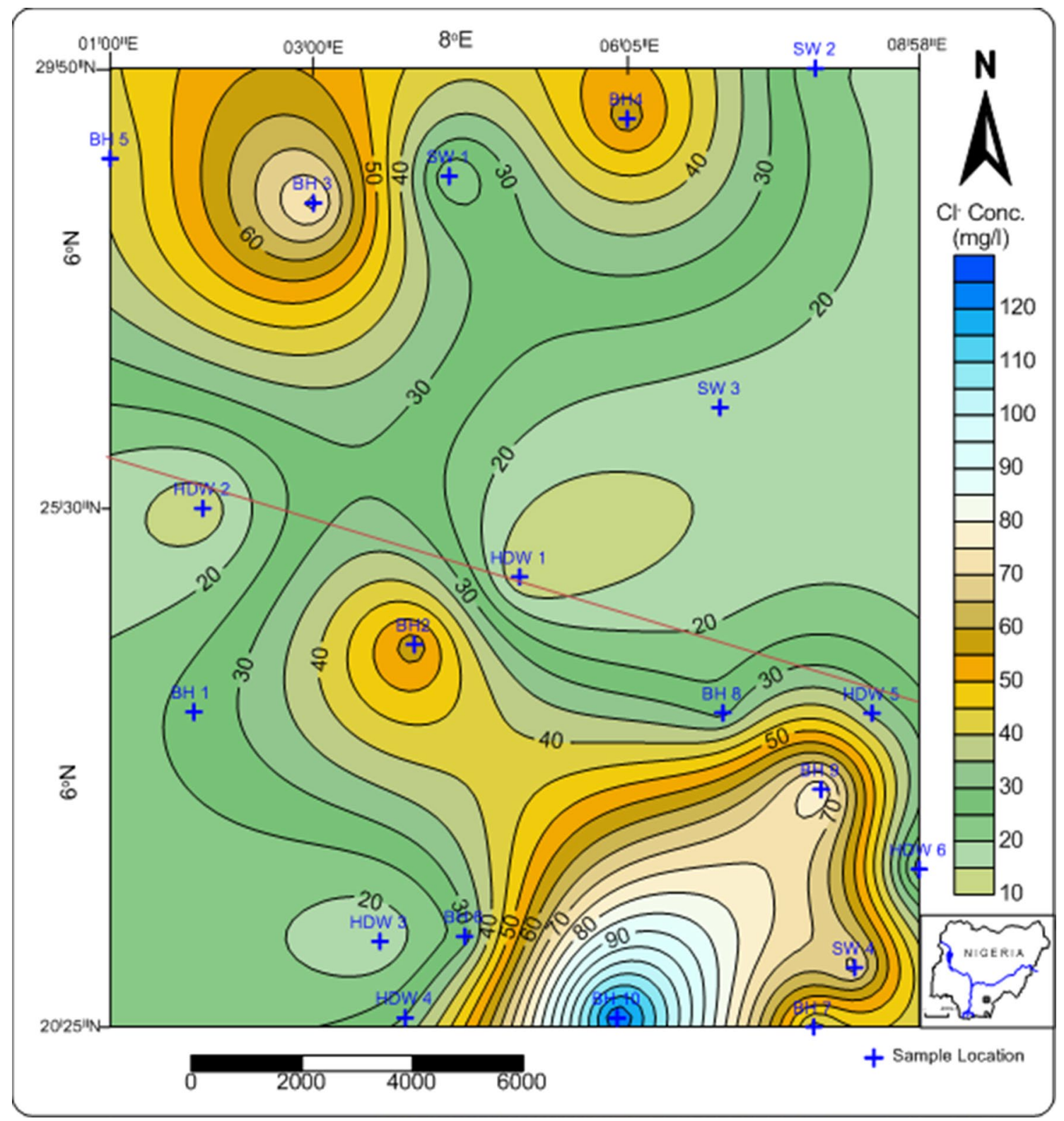

Fig. 21 Map showing the dispersion trend of chloride ion. Note: Perpendicular line indicates groundwater divide 


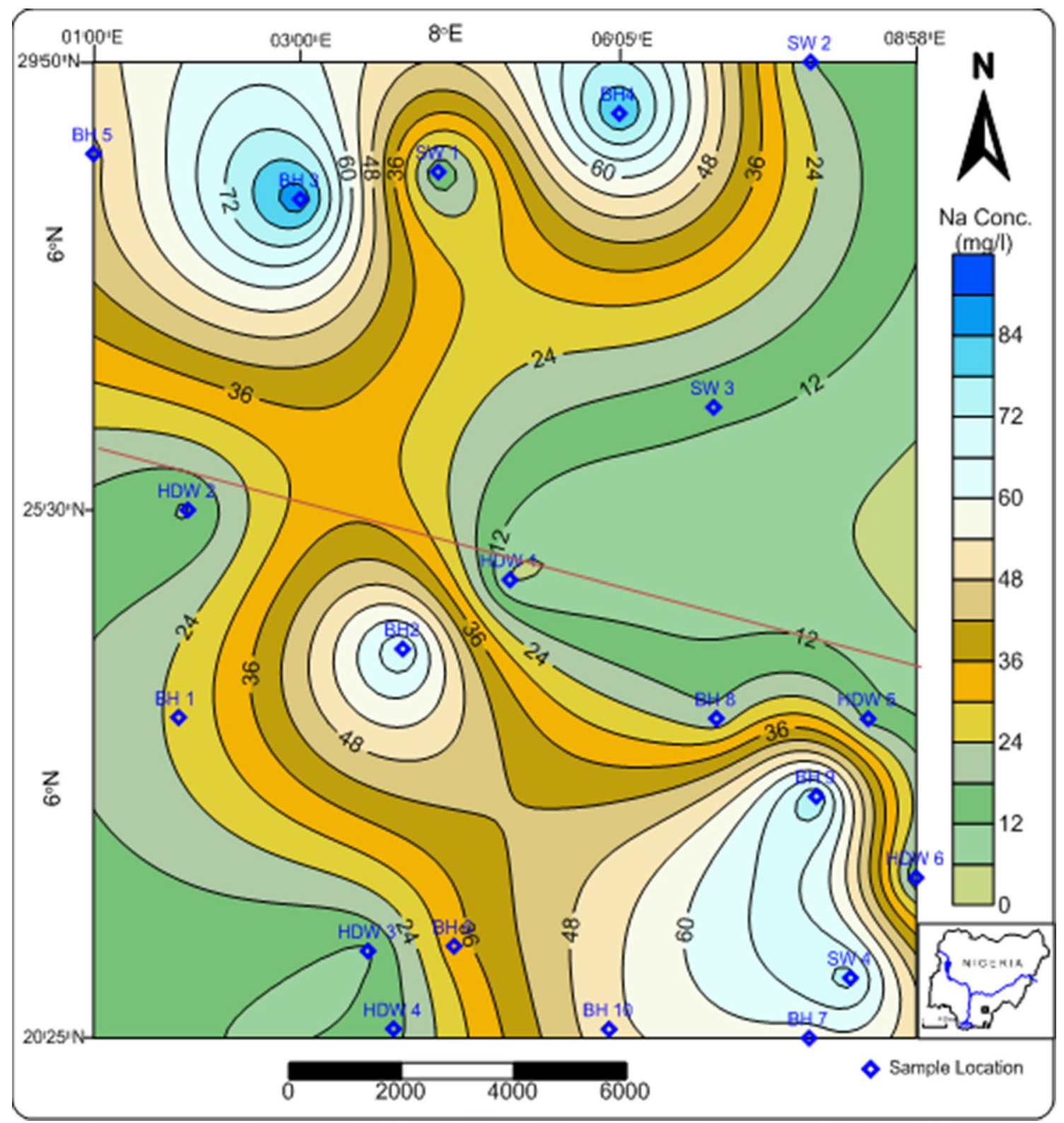

Fig. 22 Map showing the dispersion trend of sodium ion. Note: Perpendicular line indicates groundwater divide 


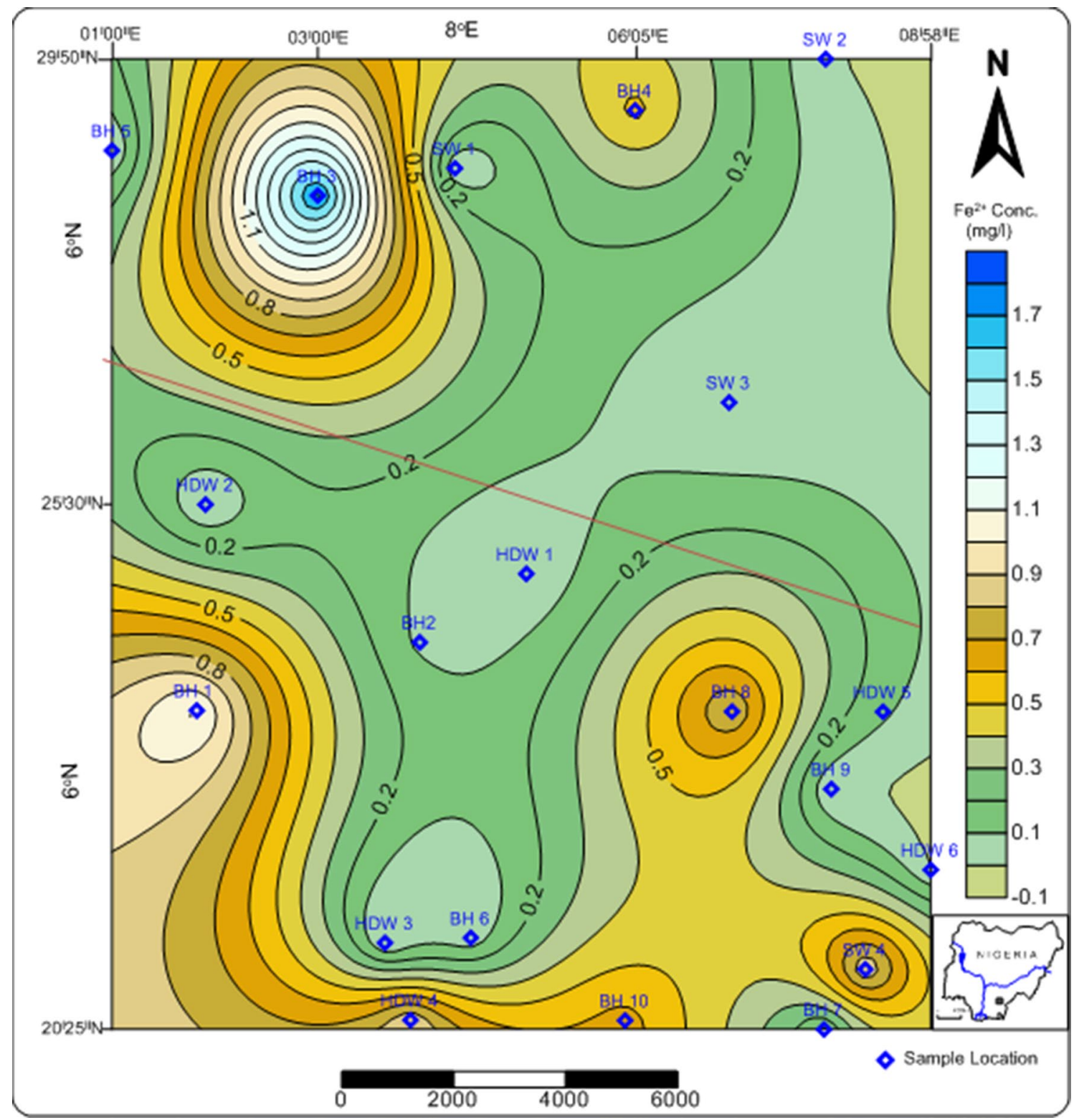

Fig. 23 Dispersion of dissolved iron. Note: Perpendicular line indicates groundwater divide 


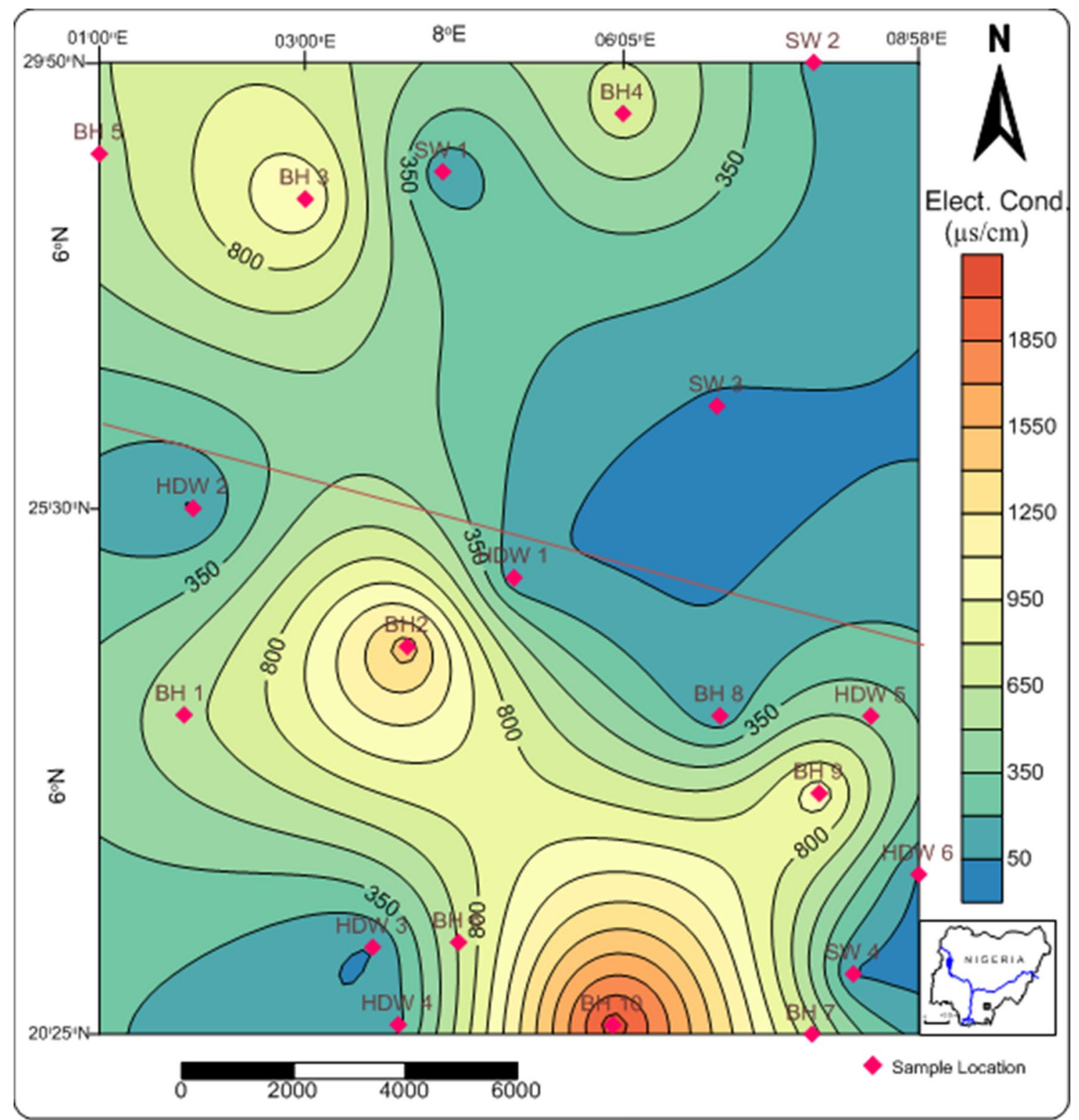

Fig. 24 Map showing the dispersion trend of EC. Note: Perpendicular line indicates groundwater divide 


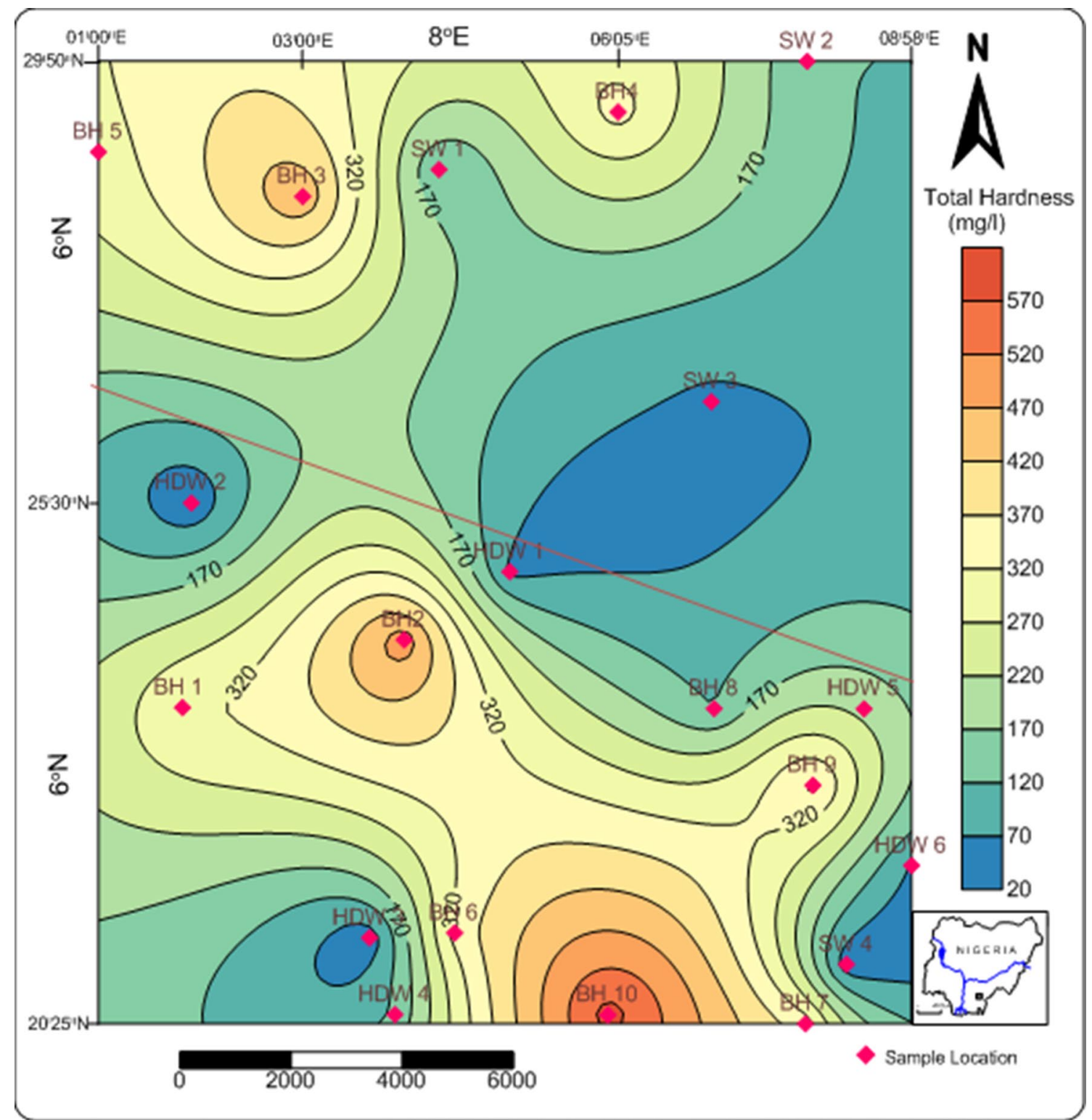

Fig. 25 Map showing the dispersion trend of total hardness (TH). Note: Perpendicular line indicates groundwater divide 
Table 5 (a) Geophysical data from Odomoke area for Fig. 6b, (b) geophysical data from Abofia area for Fig. 7b, (c) geophysical data from Agalegu area for Fig. 8b

\begin{tabular}{|c|c|c|c|c|c|c|c|c|}
\hline \multicolumn{5}{|c|}{ Location: N $6^{\circ} 28^{\prime} 54^{\prime \prime}$; E $8^{\circ} 4^{\prime} 46^{\prime \prime}$ (Odomoke area). Array type: Schlumberger } & \multicolumn{4}{|c|}{ Layered model } \\
\hline \multirow{2}{*}{$\begin{array}{l}\text { No of resistiv- } \\
\text { ity/IP data }\end{array}$} & \multicolumn{2}{|l|}{ Spacing } & \multicolumn{2}{|l|}{ Data } & \multicolumn{2}{|c|}{ Synthetic } & \multicolumn{2}{|l|}{ Difference } \\
\hline & $\mathrm{AB} / 2(\mathrm{~m})$ & $\mathrm{MN}(\mathrm{m})$ & $\begin{array}{l}\text { Apparent resistivity } \\
(\Omega-\mathrm{m}) \text { as Res } 1\end{array}$ & Chargeability (ms) & $\Omega-\mathrm{m}$ & $\mathrm{ms}$ & $\begin{array}{l}\text { Resistivity } \\
(\%)\end{array}$ & $\begin{array}{l}\text { Chargeability } \\
(\mathrm{ms})\end{array}$ \\
\hline \multicolumn{9}{|l|}{ (a) } \\
\hline 1 & 1 & 0.25 & 558.1 & 1.1 & 3276.0 & 3.6 & -110.3 & -2.4 \\
\hline 2 & 1 & 0.25 & 502.6 & 0.9 & 3274.0 & 3.6 & -117.2 & -2.7 \\
\hline 3 & 2 & 0.25 & 510.9 & 0.8 & 3241.5 & 3.6 & -114.5 & -2.8 \\
\hline 4 & 3 & 0.50 & 410.4 & 3.1 & 3093.2 & 3.7 & -653.8 & -0.6 \\
\hline 5 & 5 & 0.50 & 260.5 & 2.6 & 2822.8 & 3.8 & -983.5 & -1.2 \\
\hline 6 & 5 & 1.00 & 282.5 & 2.9 & 2818.6 & 3.8 & -897.7 & -0.9 \\
\hline 7 & 7 & 1.00 & 85.0 & 5.5 & 2329.4 & 4.3 & $* * * * *$ & 1.2 \\
\hline 8 & 10 & 1.00 & 242.9 & -2.4 & 1585.0 & 5.7 & -552.7 & -8.2 \\
\hline 9 & 10 & 1.00 & 31.5 & 13.0 & 1570.7 & 5.8 & $* * * * *$ & 7.2 \\
\hline 10 & 15 & 2.00 & 76.0 & 5.7 & 754.4 & 12.3 & -892.1 & -6.6 \\
\hline 11 & 20 & 2.00 & 229.5 & 7.4 & 426.1 & 24.4 & -85.7 & -17.0 \\
\hline 12 & 25 & 2.00 & 1.00 & 40.5 & 328.8 & 34.4 & $* * * * *$ & 6.2 \\
\hline 13 & 30 & 2.00 & 155.0 & 37.8 & 311.5 & 37.5 & -101.0 & 0.3 \\
\hline 14 & 35 & 5.00 & 273.3 & 32.8 & 317.7 & 37.0 & -16.2 & -4.2 \\
\hline 15 & 35 & 2.00 & 475.5 & 98.3 & 317.8 & 37.1 & 33.2 & 61.2 \\
\hline 16 & 40 & 5.00 & 386.1 & 13.1 & 329.4 & 35.4 & 14.7 & -22.3 \\
\hline 17 & 50 & 5.00 & 730.8 & 13.1 & 352.9 & 31.6 & 51.7 & -18.5 \\
\hline 18 & 60 & 5.00 & 284.2 & 13.9 & 372.1 & 28.4 & -30.2 & -14.5 \\
\hline 19 & 70 & 5.00 & 202.6 & 25.2 & 387.3 & 25.7 & -91.1 & -0.5 \\
\hline 20 & 80 & 5.00 & 152.0 & 53.6 & 399.5 & 23.5 & -167.9 & 30.1 \\
\hline 21 & 90 & 5.00 & 836.7 & 10.8 & 409.4 & 21.6 & 51.1 & -10.8 \\
\hline 22 & 100 & 10.00 & 573.1 & 2.1 & 417.3 & 20.1 & 27.2 & -18.0 \\
\hline 23 & 100 & 5.00 & 641.7 & 34.4 & 417.4 & 20.1 & 35.0 & 14.3 \\
\hline 24 & 150 & 10.00 & 579.9 & 12.3 & 441.7 & 15.2 & 23.8 & -2.9 \\
\hline \multicolumn{5}{|c|}{ Location: N $6^{\circ} 21^{\prime} 42^{\prime \prime} ;$ E $8^{\circ} 8^{\prime} 05^{\prime \prime}$ (Abofia area). Array type: Schlumberger } & \multicolumn{4}{|c|}{ Layered model } \\
\hline \multirow{2}{*}{$\begin{array}{l}\text { No of resistiv- } \\
\text { ity/IP data }\end{array}$} & \multicolumn{2}{|l|}{ Spacing } & \multicolumn{2}{|l|}{ Data } & \multicolumn{2}{|c|}{ Synthetic } & \multicolumn{2}{|l|}{ Difference } \\
\hline & $\mathrm{AB} / 2(\mathrm{~m})$ & $\mathrm{MN}(\mathrm{m})$ & $\begin{array}{l}\text { Apparent resistivity } \\
(\Omega-\mathrm{m}) \text { as Res } 2\end{array}$ & Chargeability (ms) & $\Omega-\mathrm{m}$ & $\mathrm{ms}$ & $\begin{array}{l}\text { Resistivity } \\
(\%)\end{array}$ & $\begin{array}{l}\text { Chargeability } \\
(\mathrm{ms})\end{array}$ \\
\hline \multicolumn{9}{|l|}{ (b) } \\
\hline 1 & 1 & 0.25 & 222.6 & 0.5 & 129.3 & 2.2 & 41.9 & -1.6 \\
\hline 2 & 1 & 0.25 & 207.7 & 0.8 & 127.6 & 2.2 & 38.6 & -1.4 \\
\hline 3 & 2 & 0.25 & 179.5 & 1.0 & 124.7 & 2.2 & 30.5 & -1.1 \\
\hline 4 & 3 & 0.05 & 379.7 & 1.4 & 108.9 & 2.2 & 71.3 & -0.8 \\
\hline 5 & 5 & 1.00 & 77.1 & 0.3 & 88.3 & 2.3 & -27.9 & -2.0 \\
\hline 6 & 5 & 1.00 & 55.6 & -0.1 & 87.9 & 2.3 & -14.0 & -2.3 \\
\hline 7 & 7 & 1.00 & 35.2 & 2.1 & 63.9 & 2.9 & -14.8 & -0.8 \\
\hline 8 & 10 & 2.00 & 35.2 & 4.3 & 44.4 & 5.5 & -26.0 & -1.2 \\
\hline 9 & 10 & 2.00 & 31.2 & 4.7 & 44.0 & 5.5 & -25.1 & -0.8 \\
\hline 10 & 15 & 2.00 & 44.9 & 8.8 & 38.9 & 11.8 & -24.9 & -3.0 \\
\hline 11 & 20 & 2.00 & 51.2 & 12.7 & 45.1 & 15.4 & -0.3 & -2.7 \\
\hline 12 & 25 & 2.00 & 60.8 & 16.7 & 53.6 & 16.9 & -4.8 & -0.2 \\
\hline 13 & 30 & 2.00 & 36.7 & 64.6 & 62.6 & 17.5 & -3.0 & 47.1 \\
\hline 14 & 35 & 5.00 & 12.3 & 55.6 & 71.6 & 17.6 & -95.0 & 38.0 \\
\hline
\end{tabular}


Table 5 (continued)

Location: N 6 21' 42"; E $8^{\circ} 8^{\prime}$ 05" (Abofia area). Array type: Schlumberger

No of resistiv- Spacing

ity/IP data

$\overline{\mathrm{AB} / 2(\mathrm{~m}) \quad \mathrm{MN}(\mathrm{m})}$

Data

Apparent resistivity Chargeability (ms)

$(\Omega-\mathrm{m})$ as Res 2

Layered model

\begin{tabular}{|c|c|c|}
\hline Synthetic & Difference & \\
\hline$\Omega-\mathrm{m}$ & $\begin{array}{l}\text { Resistivity } \\
(\%)\end{array}$ & $\begin{array}{l}\text { Chargeability } \\
(\mathrm{ms})\end{array}$ \\
\hline
\end{tabular}

\begin{tabular}{rrrrrrrrrr}
\hline 15 & 35 & 2.00 & 12.3 & 25.2 & 71.8 & 17.6 & -481.6 & 7.6 \\
16 & 40 & 5.00 & 86.2 & 13.7 & 80.7 & 17.6 & 6.4 & -3.9 \\
17 & 50 & 5.00 & 97.9 & 9.9 & 98.4 & 17.3 & -0.5 & -7.4 \\
18 & 60 & 5.00 & 73.8 & 5.4 & 115.5 & 17.0 & -56.5 & -11.7 \\
19 & 70 & 5.00 & 156.3 & 9.0 & 132.0 & 16.8 & 15.6 & -7.8 & 14 \\
20 & 80 & 5.00 & 736.5 & 29.2 & 147.8 & 16.5 & 79.9 & 12.7 \\
21 & 90 & 5.00 & 1206.1 & -27.3 & 163.0 & 16.3 & 86.5 & -43.6 \\
22 & 100 & 10.00 & 737.0 & 21.1 & 177.5 & 16.1 & 75.9 & 5.0 \\
23 & 100 & 5.00 & 686.4 & 23.1 & 177.7 & 16.0 & 74.1 & 7.1 \\
24 & 150 & 10.00 & 500.5 & 17.3 & 243.4 & 15.0 & 15.4 & 2.3 &
\end{tabular}

Location: N 6 21' 30"; E $8^{\circ} 03^{\prime}$ 01" (Agalegu). Array type: Schlumberger
No of resistiv-
ity/IP data

$\frac{\text { Spacing }}{\mathrm{AB} / 2(\mathrm{~m}) \quad \mathrm{MN}(\mathrm{m})}$

Data

Apparent resistivity Chargeability (ms) $(\Omega-\mathrm{m})$ as Res 3

Layered model

\begin{tabular}{|c|c|c|c|}
\hline$\overline{\text { Synth }}$ & & Difference & \\
\hline$\Omega-\mathrm{m}$ & $\mathrm{ms}$ & $\begin{array}{l}\text { Resistivity } \\
(\%)\end{array}$ & $\begin{array}{l}\text { Chargeability } \\
(\mathrm{ms})\end{array}$ \\
\hline
\end{tabular}

(c)

1

2

3

4

5

6

7

8

9

10

11

12

13

14

15

16

17

18

19

20

21

22

23

$\begin{array}{rrr}0.25 & 315.0 & 0.1 \\ 0.25 & 140.5 & -0.3 \\ 0.05 & 52.4 & 0.5 \\ 1.00 & 30.0 & 0.3 \\ 1.00 & 15.0 & -29.2 \\ 1.00 & 3.0 & 1.0 \\ 2.00 & 27.3 & -1.2 \\ 2.00 & 15.8 & 3.0 \\ 2.00 & 17.3 & 23.9 \\ 2.00 & 64.8 & -19.2 \\ 2.00 & 182.7 & 11.9 \\ 2.00 & 116.3 & 11.5 \\ 5.00 & 80.0 & 35.2 \\ 2.00 & 127.7 & 11.0 \\ 5.00 & 36.7 & -90.7 \\ 5.00 & 202.8 & -23.3 \\ 5.00 & 88.8 & 12.1 \\ 5.00 & 11.3 & 16.6 \\ 5.00 & 138.1 & 22.6 \\ 5.00 & 473.0 & 12.7 \\ 10.00 & 198.8 & 17.9 \\ 5.00 & 7.3 & 14.8 \\ 10.00 & 1213.8 & 6.2\end{array}$

$\begin{array}{rr}201.7 & 3.1 \\ 146.7 & 3.0 \\ 96.2 & 3.0 \\ 22.8 & 2.4 \\ 8.7 & 1.5 \\ 6.3 & 1.1 \\ 6.5 & 1.4 \\ 6.6 & 1.4 \\ 8.0 & 2.1 \\ 9.9 & 2.7 \\ 11.9 & 3.2 \\ 13.9 & 3.8 \\ 11.9 & 4.2 \\ 11.8 & 4.2 \\ 17.7 & 4.6 \\ 21.2 & 5.4 \\ 24.4 & 6.1 \\ 27.5 & 6.7 \\ 30.2 & 7.4 \\ 32.9 & 7.9 \\ 35.2 & 8.4 \\ 35.3 & 8.4 \\ 45.3 & 10.7\end{array}$

$\begin{array}{rr}36.0 & -3.0 \\ -4.4 & -3.3 \\ -83.2 & -2.5 \\ 24.0 & -2.1 \\ 42.2 & -30.7 \\ -106.5 & -0.1 \\ 76.0 & -2.6 \\ 58.6 & 1.6 \\ 53.6 & 21.8 \\ 84.7 & -21.9 \\ 93.5 & 8.7 \\ 88.0 & 0.7 \\ 80.2 & 31.0 \\ 87.6 & 6.8 \\ 51.8 & -95.3 \\ 89.5 & -28.7 \\ 72.5 & 6.0 \\ -142.3 & 9.9 \\ 78.1 & 15.2 \\ 93.1 & 4.8 \\ 82.3 & 9.5 \\ 380.1 & 6.4 \\ 96.3 & 5.5\end{array}$


Table 6 Results of the water level measurement

\begin{tabular}{|c|c|c|c|c|c|}
\hline Well no & Location name & Coordinates & $\begin{array}{l}\text { Depth to water } \\
\text { level (m) }\end{array}$ & Elevation (m) & $\begin{array}{l}\text { Hydraulic head }(\mathrm{m}) \text { or } \\
\text { height of water from } \\
\text { MSL }\end{array}$ \\
\hline 1 & Edomia & $6^{\circ} 24^{\prime} 27^{\prime \prime} \mathrm{N} ; 8^{\circ} 2^{\prime} 36^{\prime \prime} \mathrm{E}$ & 1.0 & 71 & 70.2 \\
\hline 2 & Ugbonga & $6^{\circ} 25^{\prime} 59^{\prime \prime} \mathrm{N} ; 8^{\circ} 3^{\prime} 21^{\prime \prime} \mathrm{E}$ & 3.3 & 90 & 86.7 \\
\hline 3 & Onyikwa 1 & $6^{\circ} 23^{\prime} 25^{\prime \prime} \mathrm{N} ; 8^{\circ} 7^{\prime} 33^{\prime \prime} \mathrm{E}$ & 8.0 & 57 & 49 \\
\hline 4 & Aboffia 1 & $6^{\circ} 20^{\prime} 25 \mathrm{~N} ; 8^{\circ} 7^{\prime} 15^{\prime \prime} \mathrm{E}$ & 5.9 & 49 & 43.1 \\
\hline 5 & Aboffia 2 & $6^{\circ} 20^{\prime} 20^{\prime \prime} \mathrm{N} ; 8^{\circ} 7^{\prime} 24^{\prime \prime} \mathrm{E}$ & 6.4 & 54 & 47.6 \\
\hline 6 & Ishieke 1 & $6^{\circ} 22^{\prime} 44^{\prime \prime} \mathrm{N} ; 8^{\circ} 1^{\prime} 45^{\prime \prime} \mathrm{E}$ & 2.0 & 26 & 24 \\
\hline 7 & Ishieke 2 & $6^{\circ} 22^{\prime} 47^{\prime \prime} \mathrm{N} ; 8^{\circ} 1^{\prime} 44^{\prime \prime} \mathrm{E}$ & 1.3 & 72 & 70.7 \\
\hline 8 & Ishieke 3 & $6^{\circ} 22^{\prime} 46^{\prime \prime} \mathrm{N} ; 8^{\circ} 1^{\prime} 43^{\prime \prime} \mathrm{E}$ & 1.0 & 70 & 69.2 \\
\hline 9 & Idemia & $6^{\circ} 24^{\prime} 10^{\prime \prime} \mathrm{N} ; 8^{\circ} 1^{\prime} 00^{\prime \prime} \mathrm{E}$ & 2.6 & 73 & 70.4 \\
\hline 10 & Abarigwe & $6^{\circ} 27^{\prime} 01^{\prime \prime} \mathrm{N} ; 8^{\circ} 1^{\prime} 00^{\prime \prime} \mathrm{E}$ & 4.9 & 75 & 70.3 \\
\hline 11 & Idemia 3 & $6^{\circ} 22^{\prime} 38^{\prime \prime} \mathrm{N} ; 8^{\circ} 1^{\prime} 45^{\prime \prime} \mathrm{E}$ & 1.1 & 52 & 50.9 \\
\hline 12 & Idemia 4 & $6^{\circ} 22^{\prime} 41^{\prime \prime} \mathrm{N} ; 8^{\circ} 1^{\prime} 47^{\prime \prime} \mathrm{E}$ & 2.9 & 68 & 65.1 \\
\hline 13 & Onyikwa 2 & $6^{\circ} 22^{\prime} 46^{\prime \prime} \mathrm{N} ; 8^{\circ} 7^{\prime} 11^{\prime \prime} \mathrm{E}$ & 3.0 & 70 & 94 \\
\hline 14 & Ogbaga & $6^{\circ} 22^{\prime} 31^{\prime \prime} \mathrm{N} ; 8^{\circ} 6^{\prime} 52^{\prime \prime} \mathrm{E}$ & 8.7 & 98 & 89.3 \\
\hline 15 & $\mathrm{Y}$ & $6^{\circ} 27^{\prime} 00^{\prime \prime} \mathrm{N} ; 8^{\circ} 9^{\prime} 01^{\prime \prime} \mathrm{E}$ & 13.3 & 70.5 & 57.2 \\
\hline 16 & Obegu-Aba 1 & $6^{\circ} 22^{\prime} 1^{\prime \prime} \mathrm{N} ; 8^{\circ} 6^{\prime} 36^{\prime \prime} \mathrm{E}$ & 1.0 & 48 & 47 \\
\hline 17 & Obegu-Aba 2 & $6^{\circ} 22^{\prime} 23^{\prime \prime} \mathrm{N} ; 8^{\circ} 6^{\prime} 43^{\prime \prime} \mathrm{E}$ & 1.0 & 49 & 48 \\
\hline 18 & Odomoke & $6^{\circ} 28^{\prime} 25^{\prime \prime} \mathrm{N} ; 8^{\circ} 5^{\prime} 49^{\prime \prime} \mathrm{E}$ & 3.0 & 60 & 57 \\
\hline
\end{tabular}

$\mathrm{Y}=$ Location name not ascertained

\section{References}

Aboukila EF, Nassar IN, Rashad M, Hafez M, Norton JB (2016) Reclamation of calcareous soil and improvement of squash growth using brewers' spent grain and compost. J Saudi Soc Agric Sci 17:390-397

Adelana SMA, Olasehinde PI, Bale RB, Verbka P, Edet AE, Goni IB (2008) An overview of the geology and hydrogeology of Nigeria. In: Adelana S, McDonald A (eds) Applied groundwater studies in Africa, vol 13. IAH Selected Papers on Hydrogeology, CRC press, Taylor \& Francis, pp 171-198

African Ministers' Council on Water (AMCOW 2011) Water supply and sanitation in Nigeria - turning finance into services for 2015 and beyond: an AMCOW Country Status Overview

Agumanu AE (1989) The Abakaliki and the Ebonyi formations: subdivisions of the Albian Asu river group in the southern Benue trough, Nigeria. J Afr Earth Sci (Middle East) 9(1):195-207. https ://doi.org/10.1016/0899-5362(89)90021-3

Akpodiogaga P, Ovuyovwiroye O (2010) General overview of climate change impact in Nigeria. J Hum Ecol 29(1):47-55. https://doi. org/10.1080/0p709274.2010.11906248

Alloway BJ (2013) Heavy metals and metalloids as micronutrients for plants and animals. In: Alloway B (ed) Heavy metals in soils. Environmental pollution, vol 22. Springer, Dordrecht. https://doi. org/10.1007/978-94-007-4470-7_7

Areola O, Iruegbu O, Ahmed K, Adeleke B, Leong GC (1992) Certificate of physical and human geography for secondary schools. University Press PLC, Ibadan

Ayers RS, West DW (1994) Water quality for agriculture, vol 29. FAO Irrigation and Drainage Paper, Rome

Blowes DW, Ptacek CJ, Jambor JL, Weisener CG (2003) Geochemistry of acid mine drainage. In: Lollar BS (ed) Treatise on geochemistry, vol 9. Elsevier, Amsterdam, pp 149-204. https:// doi.org/10.1016/80-08-043751-6/09137-4

Condon LE, Maxwell RM (2015) Evaluating the relationship between topography and groundwater using outputs from a continentalscale integrated hydrology model. Water Resour Res 51:66026621. https://doi.org/10.1002/2014WR016774

Domenico PA, Schwartz FW (1998) Physical and chemical hydrogeology. Wiley, New York

FAO (2013) Guidelines to control water pollution from agriculture in China. FAO of the United Nations, Rome. Water report 40: irrigation and drainage paper 55, p 197

FAO (2019) FAO soils portal: management of calcareous soils. http:// www.fao.org/soil-portal/soil-management/managementofsom eproblems-soil-calcareoussoil. Accessed 07/05/19

Fetter CW (2007) Applied hydrogeology, 2nd edn. CBS Publishers, New Delhi

Food and agriculture organization (FAO) (1985) Water quality for agriculture. Food and Agriculture Organization, Rome

Freeze AR, Cherry JA (1979) Groundwater. Prentice Hall Inc, Englewood Cliff

Fujiyama H, Magara Y (2002) Water quality and standards. Salinization of soils, vol 2. UNESCO-Encyclopedia of Life Support Systems (EOLSS). http://www.eolss.net/Eolss-sample.aspx. Accessed 05/05/2019

Horneck DS, Ellsworth JW, Hopkins BG, Sullivan DM, Stevens RG (2007) Managing salt-affected soils for crop production. PNW 601-E. Oregon State University, University of Idaho, Washington State University, Corvallis, p 24

Hussain G, Alquwaizan A, Al-Zarah A (2010) Guidelines for irrigation water quality and water management in the kingdom of Saudi Arabia: an overview. J Appl Sci 10(2):79-96 
Kacmaz H, Nakoman ME (2010) Evaluation of shallow groundwater quality for irrigation purposes in the Koprubasi Uranium Area, Manisa, Turkey. Balk Water Obs Inf Syst 25:1-9

Kehew AE (2001) Applied chemical hydrogeology. Prentice Hall, Upper Saddle River

Kelvin MH (2005) Hydrogeology (principles and practice). Blackwell, Oxford

Levy GJ, Shainberg I (2005) Encyclopedia of soil in the environment. Sodic Soils. https://doi.org/10.1016/B0-12-3485304/00218-6

Li X, Shen G (1993) Pollution from freshwater aquaculture. In: Guidelines to control water pollution from agriculture in China. FAO water report 40, pp 87-97

Li Q, Wu P, Zha X, Li X, Wu L, Gu S (2018) Effects of mining activities on evolution of water chemistry in coal-bearing aquifers in karst region of Midwestern Guizhou, China: evidences from $\delta^{13} \mathrm{C}$ of dissolved inorganic carbon and $\delta^{34} \mathrm{~S}$ of sulfate. Environ Sci Pollut Res 25(18):18038-18048. https://doi.org/10.1007/ s11356-018-1969-3

Lloyd JW, Heathcote JA (1985) Natural inorganic hydrochemistry in relation to groundwater: an introduction. Clarendon Press, Oxford University Press, New York

Marschner H (1995) Mineral nutrition of higher plants, 2nd edn. Academic Press, London

Martins Library (2011) Economic analysis of rice production in Ebonyi State, Agric Economics and Extension. http://martinslib rary.blogspot.com. Accessed 20/03/2019

McKnight TL, Hess D (2000) "Climate zones and types". Physical geography: a landscape appreciation. Prentice Hall, Upper Saddle River

Miyake Y, Yokoyama T, Yura A, Iki M, Shimizu T (2004) Ecological association of water hardness with prevalence of childhood atopic dermatitis in a Japanese urban area. Environ Res 94:33-37

Montgomery CW (2011) Environmental geology, 9th edn. McGraw Hill, New York. ISBN 978-0-07-122204-4

Munns R, Husain S, Rivelli AR, Richard AJ, Condon AG, Megan PL, Evans SL, Schachtman DP, Hare RA (2002) Avenues for increasing salt tolerance of crops, and the role of physiologically based selection traits. Plant Soil 247:93-105

National Bureau of Statistics (NBS) (2011) Annual abstract of statistics: (on population census of 2006). Federal Republic of Nigeria

National Water Policy (NWP) (2004) National water resource master plan [from 1995]. Federal Republic of Nigeria, p 28

Nielsen DL, Brock MA, Rees GN, Baldwin DS (2003) Effects of increasing salinity on freshwater ecosystems in Australia. Aust J Bot 51:655-665

Obiora SC, Umeji AC (2004) Petrographic evidence for regional burial metamorphism of the sedimentary rocks in the Lower Benue Rift. J Afr Earth Sci 38:269-277

Obiora SC, Chukwu A, Toteu SF, Davies TC (2016) Assessment of heavy metal contamination in soils around lead-zinc mining areas in Enyigba, Southeastern Nigeria. J Geol Soc India 87:453-462

Odudury P, Mamah L (2014) Integration of electrical resistivity and induced polarization, for subsurface imaging around Ihe Pond, Nsukka, Anambra Basin, Nigeria. Pac J Sci Technol 15:306-317

Oha IA, Onuoha KM, Nwegbu AN, Abba AU (2016) Interpretation of high resolution aeromagnetic data over southern Benue Trough, southeastern Nigeria. J. Earth Syst Sci 125:369-385

Ojoh KA (1992) The Southern part of the Benue Trough (Nigeria) cretaceous stratigraphy, basin analysis, paleo-oceanography and geodynamic evolution in the equatorial domain of the South Atlantic. Niger Assoc Pet Explor Bull 7(2):131-152

Okogbue CO, Ukpai NS (2013) Evaluation of trace element contents in groundwater in Abakaliki Metropolis and around the abandoned mine sites in the southern part, Southeastern, Nigeria. Environ Earth Sci 70:3351-3362
Parkhomenko EI (2013) Electrification phenomena in rocks. Springer, Berlin

Petters SW (1983) Littoral and anoxic facies in the Benue Trough. Bull Cent Explor Prod Elf-Aquitaine 7(1):361-365

Rehman F, Abouelnaga H, Harbi H, Cheema T, Ali HA (2016) Using a combined electrical resistivity imaging and induced polarization techniques with the chemical analysis in determining of groundwater pollution at Al Misk Lake, Eastern Jeddah, Saudi Arabia. Arab J Geosci. https://doi.org/10.1007/s1251 7-016-2423-9

Reyment RA (1965) Aspects of the geology of Nigeria. The stratigraphy of the Cretaceous and Cenozoic deposits. Ibadan University Press, Ibadan

Rubenowitz-Lundin E, Hiscock KM (2013) Water hardness and health effects. In: Selinus $O$ (ed) Essentials of medical geology. Springer, Dordrecht. https://doi. org/10.1007/978-94-007-4375-5_14

Satish KV, Amarender B, Dhakate R, Sankaran S, Kumar KR (2016) Assessment of groundwater quality for drinking and irrigation use shallow hard rock aquifer of Pudunagaram, Palakkad District, Kerala. Appl Water Sci 6:149-167. https://doi. org/10.1007/s13201-014-0214-6

Seilsepour M, Rashidi M (2008) Prediction of soil cation exchange capacity based on some soil physical and chemical properties. World Appl Sci 3:200-205

Subramani T, Elango L, Damodarasamy SR (2005) Groundwater quality and its suitability for drinking and agricultural use in Chithar River Basin, Tamil Nadu, India. Environ Geol 47:1099-1110

Sultana R, Salahuddin M, Ahmad MN (2018) Economic impact assessment of brackish groundwater in Kirana Hills Region, District. Int J Econ Environ Geol 9(3):19-24

Tijani MN, Loehnert EP, Uma KO (1996) Origin of saline groundwaters in Ogoja area, lower Benue Trough, Nigeria. J Afr Earth Sci 23(2):237-252

Tijani MN, Crane E, Upton K, O Dochartaigh BÉ, Bellwood-Howard I (2018) Africa groundwater atlas: hydrogeology of Nigeria. British Geological Survey. http://earthwise.bgs.ac.uk/index.php/

Tischner R (2000) Nitrate uptake and reduction in higher and lower plant. Plant Cell Environ 23(10):1005-1024. https://doi.org/10.1 046/i.1365-3040.2000.00595

Todd DK (1980) Groundwater hydrology. Wisely, New York

Ukpai SN, Okogbue CO (2017) Geophysical, geochemical and hydrological analyses of water-resource vulnerability to salinization: case of the Uburu-Okposi salt lakes and environs, southeast Nigeria. Hydrogeol J 25(7):1997-2014. https://doi. org/10.1007/s10040-017-1604-2

Ukpai SN, Nnabo PN, Eze HN (2016) Groundwater facie analysis in the upper Cross River Basin, southeast Nigeria. Environ Earth Sci 75:1345. https://doi.org/10.1007/s12665-016-6139-7

Ukpai SN, Ezeh HN, Igwe JO (2017) Aquifer prospect and vulnerability of Upper Maastrichtian sandstones: case of Ajali and Nsukka Formations in the Northern Enugu Province, southeastern Nigeria. J Afr Earth Sci 135:96-107. https://doi. org/10.1016/j.jafrearsci.2017.08.014

Uma KO, Lohnert EP (1992) Research on the saline groundwater in the Benue Trough, Nigeria. Preliminary results and projections. Zbl Geol Pal J Stuttg 1991(11):2751-2756

Umeji AC (2000) Evolution of the Abakaliki and the Anambra basins, Southeastern Nigeria, A Report submitted to the Shell Petroleum Development Company Nigeria Ltd, p 155

Umeji O (2013) The south and central Benue Trough; stratigraphic revisions. In: Ashano EC, Ogezi AE (eds) Proceedings of University of Jos PTDF chair endowment fund seminar. University of Jos, PTDF EMC, pp 145-181 
United States Department of Agriculture (USDA) (1954) Salinity Laboratory (U.S. Department of Agriculture HandBook). US Govt., Printing Office, Washington, DC

Varni M, Comas R, Weinzettel P, Dietrich S (2013) Application of water table fluctuation method to characterize the groundwater recharge in the Pampa plain, Argentina. Hydrol Sci J 58(7):1445-1455

Wilcox LV (1955) Classification and use of irrigation water, vol 969. USDA, Circular, Washington, DC, USA, p 19

Winter TC, Harvey JW, Franke OL, Alley WM (1998) Groundwater and surface water: a single resource. USGS circular 1139. United States Printing Office, Colorado, p 79
World Health Organization (WHO) (2011). Hardness in drinking-water. Background document for development of guidelines for drinkingwater quality, 4th edn. WHO, Geneva. ISBN: 9789241564199

Xu G, Fan X, Miller AJ (2012) Plant nitrogen assimilation and use efficiency. Annu Rev Plant Biol 63:153-182. https://doi.org/10.1146/ annurev-arplant-042811-105532

Publisher's Note Springer Nature remains neutral with regard to jurisdictional claims in published maps and institutional affiliations. 